Materials and Corrosion

WILEY

\title{
Effect of ammonium bisulphite and chloride on the pitting and stress corrosion cracking resistance of super duplex stainless steel pipes under combined internal pressure and axial tension
}

\begin{tabular}{|c|c|}
\hline Journal: & Materials and Corrosion \\
\hline Manuscript ID & maco.201810502.R3 \\
\hline Wiley - Manuscript type: & Article \\
\hline $\begin{array}{r}\text { Date Submitted by the } \\
\text { Author: }\end{array}$ & $\mathrm{n} / \mathrm{a}$ \\
\hline Complete List of Authors: & $\begin{array}{l}\text { Lasebikan, Daley; University of Aberdeen, Engineering } \\
\text { Akisanya, Alfred; University of Aberdeen, Engineering } \\
\text { Deans, Bill; University of Aberdeen, Engineering }\end{array}$ \\
\hline Keywords: & $\begin{array}{l}\text { Ammonium bisulphite, Chloride, Combined loading, Super Duplex } \\
\text { Stainless Steel, Mini pipe }\end{array}$ \\
\hline
\end{tabular}

\section{SCHOLARONE Manuscripts}




\begin{abstract}
Effect of ammonium bisulphite and chloride on the pitting and stress corrosion cracking resistance of super duplex stainless steel pipes under combined internal pressure and axial tension
\end{abstract}

B. A. Lasebikan*, A. R. Akisanya and W.F. Deans

School of Engineering, University of Aberdeen, Aberdeen AB24 3UE, U.K.

\begin{abstract}
Keywords:
Ammonium bisulphite, chloride, super duplex stainless steel, pitting, crack initiation, stress corrosion cracking, combined loading, axial tension, internal pressure, mini pipe.
\end{abstract}

\begin{abstract}
Combined loading of axial tension and internal pressure on the corrosion resistance of SDSS pipes at $90{ }^{\circ} \mathrm{C}$ in ammonium bisulphite $-3.5 \mathrm{wt} \% \mathrm{NaCl}$ environment was examined. The additions of ammonium bisulphite up to $1000 \mathrm{ppmw}$ increased the corrosion potential and decreased the pitting resistance. The optimum concentration for maximum resistance of the SDSS pipe under the various load conditions is $100 \mathrm{ppmw}$ ammonium bisulphite. When an internal pressure less than the nominal burst pressure at $90{ }^{\circ} \mathrm{C}$ was applied, crack initiation from pits was observed in pipes subject to internal pressure and combined loading, while no cracks was observed in nominally identical pipes subject to only axial tension. Qualification (corrosion) tests in relevant environments are usually from samples subject to single mode loading. However, in service an understanding of the relationship between service stresses caused by load and pressure and the ability of the material to resist crack initiation is required. Therefore, the use of mini pipes is proposed to better define application limits in
\end{abstract}

\footnotetext{
* Corresponding Author: daley.lasebikan@bp.com
}

$$
\text { Wiley - }{ }^{1} \mathrm{CH}
$$


corrosive environments once the failure envelope is determined in the absence of any corrosive environment.

\section{INTRODUCTION}

Duplex and super duplex stainless steel pipes are used extensively in the oil and gas and chemical process industry because of their relatively high strength and corrosion resistance compared to many low alloy steels. This is particularly the case in oil and gas wells operating at High Pressure and High Temperature (HPHT) where the high tensile strength of super duplex stainless steel (SDSS) enables the use of thinner wall pipe resulting in weight and cost savings. DSS and SDSS has a dual phase microstructure containing $\gamma$ - austenite (face centered cubic) and $\alpha$ - ferrite (body centered cubic) with approximate equal volume fraction. The microstructure and corrosion resistance are achieved by control of chemical composition, heat treatment cycle and coldworked for high strength. Due to the development of a thin protective oxide layer, SDSS are normally passive in corrosive environments that may contain, for example, $\mathrm{CO}_{2}, \mathrm{H}_{2} \mathrm{~S}$, and other sulphur containing species like ammonium bisulphite. However, such passive films are often susceptible to localised breakdown resulting in dissolution of the underlying metal by pitting that may subsequently act as initiation sites for cracks $[1,2]$.

One of the important factors for effective use of corrosion resistant alloys is the understanding of the effects of environmental and metallurgical variables on the general and localised corrosion (e.g. pitting) behaviour and on the resistance to environment assisted cracking (EAC). EAC may originate from either $\mathrm{H}_{2} \mathrm{~S}$ enhanced hydrogen absorption or $\mathrm{H}_{2} \mathrm{~S}$ enhanced breakdown of the passive oxide film by synergistic action between chloride and 
$\mathrm{H}_{2} \mathrm{~S}$. The $\mathrm{H}_{2} \mathrm{~S}$ content and salinity of the aqueous phase are critical variables affecting EAC susceptibility in the production environment [3-6]. Past failures of cold worked DSS [7, 8] and SDSS [9] tubulars used in oil and gas wells clearly demonstrate that the physical understanding of EAC remains incomplete despite extensive research on the subject over many decades.

A typical completion system for an oil and gas well is made up of concentric tubulars, see Figure 1. The production tubular, which transports the hydrocarbon from the production zone to the wellhead, is sometimes made of DSS or SDSS depending on the $\mathrm{CO}_{2}$ and $\mathrm{H}_{2} \mathrm{~S}$ content of the hydrocarbon. Specialised cement is used to isolate the production casing from the surrounding formation and to provide structural integrity. The production annulus, i.e. the space between the production tubing and production casing (annulus A in Figure 1) normally contains brine (e.g. $\mathrm{CaCl}_{2}, \mathrm{NaCl}, \mathrm{NaCl} / \mathrm{NaBr}, \mathrm{CaCl}_{2} / \mathrm{CaBr}_{2}$ etc.) and/or treated water (deionised, seawater etc.) to provide hydrostatic head against the ingress of any well fluids through the packer that seals the void between the production tubing and production casing just above the liner. The brine or water is treated using sodium bisulphite $\left(\mathrm{NaHSO}_{3}\right)$ or ammonium bisulphite $\left(\mathrm{NH}_{4} \mathrm{HSO}_{3}\right)$ to reduce oxygen corrosion to negligible levels. Ammonium bisulphite is the main oxygen scavenger used in the annulus fluid. Experience has shown that brine that contains less than 10 ppbw (part per billion by weight) of dissolved oxygen is deaerated and therefore not corrosive to the carbon steel casing and production tubing [10]. The effectiveness of ammonium bisulphite as oxygen scavenger is presented elsewhere [11]. Ammonium bisulphite has been implicated in the corrosion related failure of production tubular used in a few HPHT wells [8, 9]. Thus, material selection for production 
tubulars in well completion requires an understanding of the relationship between service stresses and the ability of the material to resist crack initiation in the service environment. In HPHT wells axial load is limited (weight of tubing string) and internal pressure is dominant.

Most of the published research to-date on pitting and stress corrosion cracking are based on single mode or uniaxial loading of the material in $\mathrm{CO}_{2} / \mathrm{H}_{2} \mathrm{~S}$ or chloride environment. Test results from four-point bend specimens of austenitic stainless steel in chloride environment showed increased susceptibility to pitting corrosion with increased pre-existing surface roughness or damage [12] while compact tension test results in simulated boiling water reactor conditions showed that ppb level of chloride may result in fast stress corrosion cracking of low alloy steels [13]. Stress corrosion cracking of 22Cr and 25Cr SDSS under evaporative seawater conditions using uniaxial tensile specimen has been shown to depend on the level of applied stress and the test temperature; as the applied stress increased the threshold temperature for corrosion and cracking decreased [14]. A summary of the effects of intrinsic material parameters (e.g. chemical composition, microstructure and surface condition) and environment (e.g. $\mathrm{pH}$, temperature, concentration of aggressive species and dissolved oxygen) on the initiation and growth of pits in metals has recently been presented by Soltis [15]. Although Keitelman and Alvarez elucidation of the localised acidification pitting model (initiation and growth) by Galvele stated that it did not consider the interactions between dissolved metal ions and chloride or other anionic species in solution; they concluded that laboratory experiments and field experience with alloys like $22 \mathrm{Cr}$ and 25Cr SDSS confirmed quantitatively the predictions of Galvele's model [16]. The main point 
of the mechanism is that localised $\mathrm{pH}$ drop on the anode surface is necessary to sustain pitting.

Unlike corrosion in chloride environment and $\mathrm{H}_{2} \mathrm{~S}$, there has been limited study of corrosion in sulphite environment. Hornlund et al. [17] examined the diffusion of hydrogen during cathodic protection of carbon steel in a solution of $\mathrm{NaCl}$ with added sulphite. The authors are not aware of any previous study of the corrosion of SDSS tubulars subject to combined loading of axial tension and internal pressure in ammonium bisulphite-brine environment. Practical situations are closer to combined loading unlike single mode loading typically used for corrosion / material tests. For example, the $\mathrm{C}$ ring test sample simulate the circumferential stresses induced on the tubing by internal pressure (hoop stress) where bent beam and constant load tests are performed to reproduce longitudinal stresses induced by the weight of the production tubing string in a well completion. The aim of the current study is to assess the pitting corrosion behaviour and the susceptibility to stress corrosion cracking (SCC) under combined loading (axial tension and internal pressure) of SDSS pipes in ammonium bisulphite-chloride environment without the presence of $\mathrm{CO}_{2}$ or $\mathrm{H}_{2} \mathrm{~S}$. The results of the corrosion tests would provide a better assessment of the effect of ammonium bisulphite on corrosion resistance and behaviour of SDSS pipes in a well completion production annulus that is nominally free of $\mathrm{CO}_{2}$ or $\mathrm{H}_{2} \mathrm{~S}$.

\section{EXPERIMENTAL PROCEDURES}

\subsection{Material and specimen preparation}

A $25 \mathrm{Cr}$ SDSS with the element composition shown in Table 1 was considered and Figure 2 illustrates the normal microstructure in the longitudinal (rolling) and transverse direction of 
the SDSS as received Sumitomo pipes from a well completion. The ferrite and austenite ratio were $49 \%$ and $51 \%$ respectively. The mechanical properties of the material are presented elsewhere [18]. For completeness, the effects of temperature on the Young's modulus, yield strength and the ultimate tensile strength of the material are shown in Table 2. The element composition in Table 1 indicates the material has a Pitting Resistance Equivalent Number $\left(\mathrm{PREN}_{32}\right)$ of 45 for the PREN formula in equation. PREN is a measure of the intrinsic resistance of a material to pitting corrosion and is determined from the element composition (in percentage weight) of the material [19]:

$$
\operatorname{PREN}_{a}=\mathrm{Cr}+3.3 \mathrm{Mo}+a \mathrm{~N}
$$

where " $a$ " is a constant that ranges from 16 to 32 .

Mini pipe samples were machined from the parent tubing of the SDSS along the longitudinal rolling direction. Airao et al. found that surface finish obtained in wet machining of SDSS were much better compared to dry machining [20]. Coolant was used for all cutting and machining processes to minimise the effect of the heat associated with the machine on the mechanical properties and SDSS microstructure and ensure a good surface finish. The mini pipes (Figure 3) have an outside diameter of $8 \mathrm{~mm}$, wall thickness of $0.25 \mathrm{~mm} \pm 0.2 \mu \mathrm{m}$ (tolerance) and a gauge length of $25 \mathrm{~mm}$ including $2.5 \mathrm{~mm}$ thick section (spanner flat) before the treads to facilitate fastening to fixtures prior to application of the epoxy resin (Figure 4). The surface of the pipe was mechanically polished in the hoop direction by using a P360 grit and subsequently using a P600 grit $(30 \mu \mathrm{m})$. The surface was then cleaned with acetone.

$$
\text { Wiley }-6 \text { CH }
$$


Titanium wire inserted in a $1 \mathrm{~mm}$ diameter shrink sleeve was spot welded to one end of the mini pipe to facilitate current measurement during corrosion test. The pipes were then connected to ceramic adaptors (Manufactured by Dynamic Ceramic, Crewe Hall Enterprise Park, Weston Road, Crewe, CW1 6UA, UK) as shown in Figure 4. To avoid crevice corrosion, the areas of the pipe near the connection ends were covered in epoxy resin (twopack araldite) leaving an exposure surface area of $6 \mathrm{~cm}^{2}$ in the gauge section (see Figure 4).

\subsection{Test Environment}

The solutions used in the corrosion tests were $0.1,1$ and $3.5 \mathrm{wt} \% \mathrm{NaCl}$ plus various concentration of ammonium bisulphite (0, 100, 500 and $1000 \mathrm{ppmw})$. Here and thereafter the unit ppm (part per million) for the concentration of ammonium bisulphite is in weight. Each test solution was made with analytical grade $\mathrm{NaCl}$ in deionised water plus additions of various concentration of ammonium bisulphite. The $\mathrm{pH}$ and dissolved oxygen (DO) of the solution were measured at room temperature using electrodes and DO probe supplied by Fisher Scientific. Table 3 shows the $\mathrm{pH}$ and DO of the various solutions prior to heating the solution to the test temperature of $90^{\circ} \mathrm{C}$.

\subsection{Corrosion tests}

\section{Critical Pitting Temperature (CPT)}

ASTM G48 [21] test method is widely used to determine the pitting resistance of corrosion resistant alloys (CRAs) in a standard environment and can provide useful information regarding the susceptibility of specific materials to pitting. The procedure involves the immersion of the sample in the test environment at the temperature of interest for 72 hours. The sample is then examined under an optical microscope to detect the presence of pits. If pits are not detected the procedure is repeated at an increased temperature until pits are

$$
\text { Wiley - VCH }
$$


detected in the sample. This temperature is taken as the CPT. Thus, CPT is the maximum temperature below which no pitting corrosion is expected and above which pitting corrosion is highly likely to occur when the material is exposed to the test environment.

Immersion test in Ferric chloride environment was carried out on a sample removed from the 7" cold worked SDSS tubing under consideration according to ASTM G48 standard method E [21] described above; this test gave a CPT value of $85^{\circ} \mathrm{C} . \mathrm{CPT}$ of Hot Isostatic pressed (manufactured) SDSS 32707 in $3.5 \mathrm{wt} \% \mathrm{NaCl}$ solution investigated by $\mathrm{Xu}$ et al. in potentiodynamic corrosion tests measured between 55 and $65^{\circ} \mathrm{C}$ [22]. However, the CPT of SDSS was determined in 6\% Ferric Chloride according to the ASTM G48 tests at $80{ }^{\circ} \mathrm{C}$ by another researcher [23]. Thus, potentiodynamic corrosion tests (described below) were carried out at $90^{\circ} \mathrm{C}$.

\section{Potentiodynamic Corrosion Tests}

The corrosion tests in this study were based on potentiodynamic polarisation technique [24] which can provide useful information regarding the susceptibility of specific materials to corrosion in a particular environment. The tests were carried out in a purposely-designed and manufactured HPHT autoclave [25]. The autoclave was filled with the test solution (i.e. the electrolyte) and an electrochemical cell consisting of four electrodes was made up as illustrated in Figure 5. The volume of the solution used was $1000 \mathrm{ml}$; this is consistent with the recommended minimum $100 \mathrm{ml}$ per square centimetre of the exposed surface area of the mini pipe which was $6 \mathrm{~cm}^{2}$ [26]. The reference electrode (RE) used in all the experiment was a silver|silver-chloride $(\mathrm{Ag} \mid \mathrm{AgCl})$ half cell (supplied by Fisher Scientific) in a $3.5 \mathrm{M}$ 
potassium chloride $(\mathrm{KCl})$ solution; the reference electrode was used to monitor and maintain the potential at the surface of the working electrode (WE). The SDSS mini pipe was the WE whilst two graphite rods were used as counter electrodes (AUX).

The four electrodes were connected to a computer-controlled potentiostat (Princeton Applied Research Model 263A Potentiostat/Galvanostat). The potential of the working electrode was varied at a selected rate by the application of a current through the electrolyte and the resulting current and potential between the WE and RE are monitored and recorded by a potentiostat; the relationship between the current and potential is used to assess the onset of pitting (breakdown of passivation) and repassivation.

The voltage and current in the electrochemical cell were continuously recorded using the potentiostat in-built data logger. Using the computer-controlled potentiostat, the WE was polarised in the noble direction from $25 \mathrm{mV}$ below the open circuit potential (to minimise cathodic polarisation and probable hydrogen adsorption) at a scan rate of $1 \mathrm{mV} / \mathrm{s}$ and terminated at $0.5 \mathrm{~mA}$. During anodic polarisation, the increase in potential of the mini pipe results in loss of electrons. The scan rate must be slow enough to allow the rate determining step of the overall reaction. Thus, the anodic dissolution rate in the various test environments is a measure of the susceptibility of the pipe to pitting. The onset of pitting was determined as the potential at which the recorded current density suddenly increased and exceeded 100 $\mu \mathrm{A} / \mathrm{cm}^{2}$ and did not fall below this value for 60 seconds. This approach was used to determine the pitting potential, $E_{p}$, which provides a measure of the susceptibility of the SDSS pipes to pitting in the ammonium bisulphite-chloride environment. The 
potentiodynamic test was performed in duplicates to ensure tests were repeatable and representative.

The electrical isolation of the mini pipes from the load fixtures using ceramic adaptors, the use of earth-to-earth connection between the autoclave and potentiostat and the screening of all the cables used for all connections (RE, WE, AUX and autoclave to potentiostat) ensured adequate shielding and minimisation of noise and interference in the measured potential and current.

Two sets of corrosion tests were performed at a temperature of $90^{\circ} \mathrm{C}$. First, the external surface of the pipe at the gauge length was exposed to each test solution inside the autoclave with no external mechanical loads applied to the pipes; this is referred to as the reference test. A separate and second set of tests was carried out with axial tension and/or internal pressure applied to the mini pipe while the external surface was exposed to the test solution inside the autoclave. In both cases, the potentiostat was used to monitor and determine the pitting potential as described above. Axial tension was applied in displacement control and at a crosshead speed of $0.5 \mathrm{~mm} / \mathrm{min}$ using a screw-driven Instron testing machine while the internal pressure was applied using a hydraulic hand pump as described in [27]; the pressuring medium was hydraulic oil.

Three load cases were considered: (i) an axial tension of $568 \mathrm{MPa}$ which was within the elastic limit based on the material properties at $90^{\circ} \mathrm{C}$ (Table 2), (ii) an internal pressure of 48.3 $\mathrm{MPa}$, which was 0.85 of the average measured burst pressure at $90{ }^{\circ} \mathrm{C}$ (and 0.72 of burst 
pressure at room temperature), and (iii) a combined axial tension of $568 \mathrm{MPa}$ and internal pressure of 48.3 $\mathrm{MPa}$. For the combined loading, the axial tension was first applied to the mini pipe followed by the application of the internal pressure while the axial tension was kept constant. In the absence of any corrosive environment, the experimentally measured average burst pressure at $90{ }^{\circ} \mathrm{C}$ (without any externally applied axial load) was found to be 56.1 MPa, while failure under combined loading at $90{ }^{\circ} \mathrm{C}$ occurred at an internal pressure of $52 \mathrm{MPa}$ and axial load of $665 \mathrm{MPa}$ [27]. Thus, the chosen values of the axial load and internal pressure for the current study are lower than those required for the failure of the pipe in the absence of any corrosive environment as illustrated in Figure 6. This is important as the purpose of the current study is to assess the susceptibility to pitting and pitting induced failure in the pipes at loads that are below the nominal failure loads without the ammonium bisulphite-chloride environment.

For each of the load cases, the autoclave containing the mini pipe was filled with the test solution and solution heated to the test temperature using a heating jacket on the outer surface of the autoclave. The pipes were left at open circuit condition during the heating process until the test temperature of $90^{\circ} \mathrm{C}$ was achieved (which took $\sim 1$ hour). Once the test temperature was attained, the required load was applied in increment. When the load was applied, the rupture of surface film on the specimen produces an immediate increase in anodic current, which then decreases with time as repassivation occurs. Allowance was made to ensure there was enough time for the stabilisation ( 15 minutes) of OCP (open circuit potential) before the corrosion test commenced by application of potential to the cell at a rate of $1 \mathrm{mV} / \mathrm{s}$. No specific attempt was made to ensure the test solution was oxygen free at the

$$
\text { Wiley }-11_{C H}
$$


test temperature, but small plastic hollow spheres were used to cover the $1000 \mathrm{ml}$ solution to minimise evaporation and ensure stable test temperature.

\subsection{Morphology of corrosion attack}

The external surface of the mini pipe samples after corrosion tests were cleaned before examination. Optical microscope was used to investigate the presence of pits after the ASTM G48 tests. A Hitachi S-520 scanning electron microscope (SEM) was used to examine corrosion morphology on the external surface of the pipe after potentiodynamic polarisation tests.

\section{RESULTS AND DISCUSSION}

\subsection{Critical pitting temperature (CPT)}

Immersion tests carried out according to the ASTM G48 standard method E [21] gave a CPT of $85{ }^{\circ} \mathrm{C}$ for the SDSS pipe material considered in this study. Presence of pit was confirmed by microscopic examination of one of the samples; this revealed pits of at least $25 \mu \mathrm{m}$ wide (Figure 7). The focus of the current study is the determination of the pitting potential in the various chloride-ammonium bisulphite environments under combined load. Consequently, no attempt was made in the current study to determine the phase where the pits were initiated within the SDSS material. However, pitting corrosion study in chloride environment of $25 \mathrm{Cr}$ SDSS similar to the material considered in the current study [28] and of DSS 2204 [29] showed that pitting initiated from the austenite phase and the ferrite/austenite grain boundary.

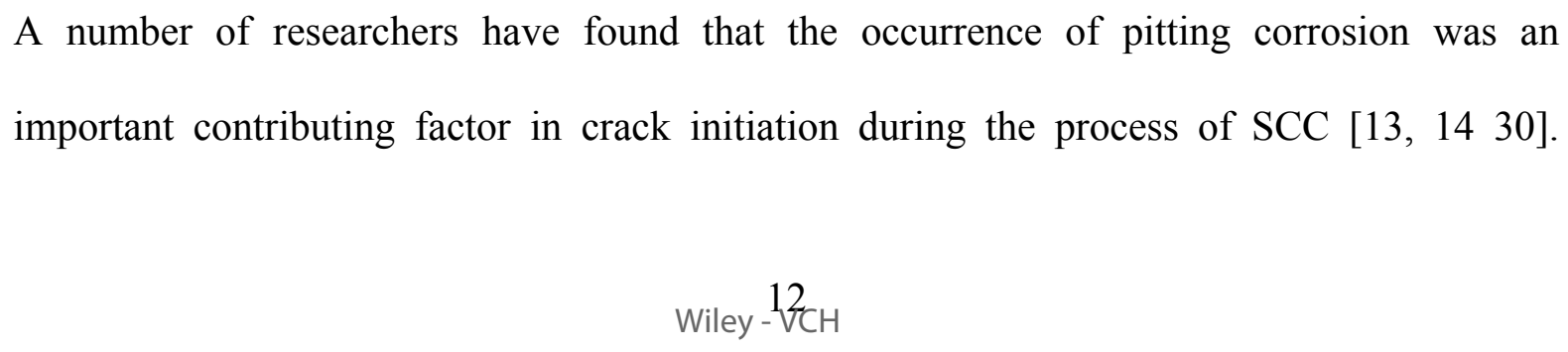


Furthermore, many other researchers have shown that the temperature of maximum SCC susceptibility is between $80-120{ }^{\circ} \mathrm{C}$ [3]. Van Gelder et al. [31] found that DSS (UNS 31803) when subjected to slow plastic strain was susceptible to SCC in sulphide - chloride media at temperatures higher than $80^{\circ} \mathrm{C}$.

\subsection{Electrochemical corrosion - effects of ammonium bisulphite concentration}

The experimental set-up was based on the exposure of the SDSS mini pipe to $1000 \mathrm{ml}$ of 0.1 , 1 and $3.5 \mathrm{wt} \% \mathrm{NaCl}$ solutions with the addition of various concentration of ammonium bisulphite $(0,100,500$ and 1000 ppmw). Figure 8 shows the typical $\log (i)-E$ response for the mini pipe specimens subject to no external loading in 0.1 and $3.5 \mathrm{wt} \% \mathrm{NaCl}$ solution. The forward scan was started just below the OCP or $E_{\text {corr }}$. Passivation was indicated by either constant current or infinitesimal current increment over a finite potential range. This section of the curve is referred to as the passive region. As the current and potential increase, a breakdown in the passive film is inevitable unless the pipe is immune to corrosion in the environment. When the potential increases to a point where growth of pits occur (metastable pitting also visible), a breakdown potential $\left(E_{p}\right)$ was determined. This potential was defined as the point, which is beyond the passive region, where the current density suddenly increases and exceeds $100 \mu \mathrm{A} / \mathrm{cm}^{2}$.

The difference between OCP and $E_{p}$ provides an indication of the resistance to pitting in all the test environments. The OCP and $E_{p}$ data from the polarisation curves are compared in Table 4 for two nominally identical specimens. There was some slight variability in the measured OCP and $E_{p}$, but test repeatability was generally good and most of the corresponding data for the two nominally identical mini pipes are within $20 \mathrm{mV}_{\mathrm{Ag} \mid \mathrm{AgCl}}$ from

$$
\text { Wiley }-13 \mathrm{CH}
$$


each other. The slight variation in the measured OCP and $E_{p}$ for the two nominally identical pipes may be due to clogged frit, decrease in saturation of the solution in the electrode or a slight difference in pipe surface roughness. Overall the test results for the chlorideammonium bisulphite solution showed less variability in comparison to the chloride only solution for OCP data because ammonium bisulphite works as a passivating inhibitor [10].

It was noted that the pitting potential, $E_{p}$, in the $3.5 \mathrm{wt} \% \mathrm{NaCl}$ solution with the addition of ammonium bisulphite was lower than the pitting potentials in the corresponding 0.1 and 1 $\mathrm{wt} \% \mathrm{NaCl}$ solutions apart from the $1 \mathrm{wt} \% \mathrm{NaCl}$ plus 100 ppmw ammonium bisulphite. Overall the trend of the $\log (i)-E$ plot (Figure 8) and $\mathrm{pH}$ measurement at ambient conditions (Table 3) confirmed that $3.5 \mathrm{wt} \% \mathrm{NaCl}$ solution (with or without the ammonium bisulphite) had the most effect on pitting. This reinforces the assertion that the presence of chlorides is a key component in the pitting of the external surface of the SDSS mini pipes at the test temperature of $90{ }^{\circ} \mathrm{C}$.

The addition of ammonium bisulphite generally resulted in the OCP becoming more negative and in a reduction of the pitting resistance, determined by the pitting potential, $E_{p}$. Ammonium bisulphite is a reducing agent and the reaction products in a chloride solution include sulphide. As the concentration of the ammonium bisulphite increases the sulphide level increases. The synergistic action of chloride and sulphide decreases the resistance to pitting. This finding is consistent with the results obtained by Tsai et al. [32] who found the corrosion potential of 2205 duplex stainless steel tensile samples shifted in the less noble direction with increasing sulphide concentration in $3.5 \mathrm{wt} \% \mathrm{NaCl}$ solutions.

$$
\text { Wiley }-14 C H
$$


Dissolved oxygen and $\mathrm{pH}$ can have a major effect on the corrosion behaviour of metals. In the current study, the $\mathrm{pH}$ and DO were only measured at room temperature (see Table 3 ) and not at the test temperature of $90{ }^{\circ} \mathrm{C}$, as the test temperature was outside the working temperature range of $50{ }^{\circ} \mathrm{C}$ for both the $\mathrm{pH}$ and $\mathrm{DO}$ meters. In an open system such as the one considered in the current study, the DO decreases as the temperature is increased above about $80{ }^{\circ} \mathrm{C}$ because oxygen is able to escape from the solution and the solubility of oxygen decreases as the temperature is increased. The $\mathrm{pH}$ of the test solution is therefore expected to decrease slightly as the temperature is increased from room temperature to $90{ }^{\circ} \mathrm{C}$. It is surmised that the effect of the small amount of DO and slight decrease in the $\mathrm{pH}$ due to the elevated temperature on the corrosion behaviour of the material is negligible compared to that of the solution, i.e. chloride-ammonium bisulphite.

\subsection{Electrochemical corrosion - effects of external loading}

The focus of the current study is the determination of the pitting potential in the various chloride- ammonium bisulphite environments under combined loads, i.e. axial load and internal pressure. Electrochemical polarisation studies of a pipe subject to combined loads in an aqueous environment have seldom been reported. As the $3.5 \mathrm{wt} \% \mathrm{NaCl}$ had the most effect on pitting for the reference test, the potentiodynamic tests were carried out on the mini pipe with load application in $3.5 \mathrm{wt} \% \mathrm{NaCl}$ and various concentration of ammonium bisulphite. An axial load of $568 \mathrm{MPa}$, internal pressure of $48.3 \mathrm{MPa}$, and combined axial tension and internal pressure of $568 \mathrm{MPa}$ and $48.3 \mathrm{MPa}$ respectively were applied to the mini pipe in all the solutions.

$$
\text { Wiley }-15 \mathrm{CH}
$$


Polarisation curves are shown in Figure 9 for two nominally identical mini pipes subject to the combined axial tension and internal pressure in $3.5 \mathrm{wt} \% \mathrm{NaCl}$ (Figure $9 \mathrm{a}$ ) and in $3.5 \mathrm{wt} \%$ $\mathrm{NaCl}$ plus 100 ppmw of ammonium bisulphite (Figure 9b). There is a satisfactory level of consistency and repeatability in the results. The pitting potentials were $408 \mathrm{mV}_{\mathrm{Ag} \mid \mathrm{AgCl}}$ (Pipe A), $390 \mathrm{mV}_{\mathrm{Ag} \mid \mathrm{AgCl}}$ (Pipe B) in $3.5 \mathrm{wt} \% \mathrm{NaCl}$ solution while the potentials were 520 $\mathrm{mV}_{\mathrm{Ag} \mid \mathrm{AgCl}}($ Pipe A) and $503 \mathrm{mV}$ (Pipe B) in $3.5 \mathrm{wt} \% \mathrm{NaCl}$ plus $100 \mathrm{ppmw}$ of ammonium bisulphite. Although most of the tests for each test condition were carried out on at least two nominally identical mini pipes, in the following only typical polarisation curves for one of the tested mini pipes for each test condition are presented due to the level of consistency in the results (as shown in Figure 9).

Figure 10 shows the polarisation curves for different loading conditions in the respective test solutions. The corrosion behaviour of the mini pipe in each solution was found to be stress and environment dependent. The polarisation curves for the mini pipes tested in each solution and load condition all exhibit anodic behaviour with distinct pitting potentials marked by a rapid rise in the current density.

The polarisation curves for $\log (i)-E$ response in $3.5 \mathrm{wt} \% \mathrm{NaCl}$ (and no ammonium bisulphite) is compared in Figure 10a for different external loading conditions. The pitting potential shifted in the less noble direction with the application of external load and the potential range corresponding to the passive region decreased. The only exception was the axial tension test where the pitting potential was nobler than the reference test although there was indication of metastable pitting, initial pit growth (current density briefly exceeded 100

$$
\text { Wiley }-16_{\mathrm{CH}}
$$


$\mu \mathrm{A} / \mathrm{cm}^{2}$ ), and temporary repassivation before continuous pit growth. The breakdown potential for two nominally identical mini pipes subject to only axial tension was found to be $536 \mathrm{mV}_{\mathrm{Ag} \mid \mathrm{AgCl}}$ and $451 \mathrm{mV}_{\mathrm{Ag} \mid \mathrm{AgCl}}$. The pitting potentials for two mini pipes subject to internal pressure only were found to be $363 \mathrm{mV}_{\mathrm{Ag} \mid \mathrm{AgCl}}$ and $324 \mathrm{mV}_{\mathrm{Ag} \mid \mathrm{AgCl}}$, which are slightly smaller to the corresponding values for mini pipes subject to combined loading of $469 \mathrm{mV}_{\mathrm{Ag} \mid \mathrm{AgCl}}$ and $409 \mathrm{mV}_{\mathrm{Ag} \mid \mathrm{AgCl}}$.

The uniaxial strain at the onset of plastic yielding of the SDSS material under consideration at the test temperature of $90^{\circ} \mathrm{C}$ was found to be $0.3 \%$ [18]. The applied axial stress of 568 MPa was below the elastic limit, however for internal pressure only and combined loading, the pipe was stressed beyond the elastic limit but below the level that caused burst or failure, see Figure 6. The application of only axial tensile stress of $568 \mathrm{MPa}$, only internal pressure of 48.3 MPa and a combined loading of axial stress of $568 \mathrm{MPa}$ and internal pressure of 48.3 MPa induced respectively an axial strain of $\varepsilon_{a}$ and a hoop strain $\varepsilon_{h}$ of $\left(\varepsilon_{a}, \varepsilon_{h}\right)=(0.2 \%,-$ $0.07 \%),(0.1 \%, 0.35 \%)$ and $(0.55 \%, 0.7 \%)$ [27]. Thus, the pipes experienced some plastic deformation when subject to only internal pressure of $48.3 \mathrm{MPa}$ or combined loading axial stress of $568 \mathrm{MPa}$ and internal pressure of $48.3 \mathrm{MPa}$. It was observed that the pitting potential $E_{p}$ for specimens where the applied load resulted in plastic deformation (i.e. internal pressure only and combined loading) is lower than that for specimens where there is no plastic deformation (reference and axial tension only). A lower pitting potential observed on the surface of the mini pipe under plastic deformation was due to the inherent instability of the passive film during plastic deformation which would facilitate initiation sites for pits in this environment. This is consistent with the findings of Renton et al. [33] which showed 
that pitting potential of $25 \mathrm{Cr}$ SDSS subject to axial tension decreases with increasing level of plastic deformation. It is important to note that a small change in wall thickness $( \pm 0.2 \mu \mathrm{m}$ tolerance) can lead to a lower axial load capacity or higher strain in the pipe; thus, affect the pitting potential. However, in addition to checks carried out to confirm pipe diameter the consistency in the results of the mini pipe mechanical load tests to determine failure envelope and the results of the corrosion tests particularly under various loads indicate that the mini pipes were machined to the wall thickness specified, i.e. $0.25 \mathrm{~mm}$. Although the deformation of the mini pipe under various loading conditions would result in a nominal increase in effective surface area; the same surface area was used to determine the pitting potential for all mini pipes during the corrosion tests. For example, the mini pipe strain during axial loading was $0.2 \%$ compared to $2.5 \%$ and a $4 \mathrm{~mm}$ elongation on failure; thus, the increase in length of the mini pipe is negligible for the loading condition during the corrosion tests. It should also be noted that for the axial loading tests there is slight reduction in the diameter of the pipe due to compressive strain. For the internal pressure tests and combined load tests the length of the pipe on failure was the same $(60 \mathrm{~mm})$; the hoop strain was $0.3 \%$ on loading compared to above $2 \%$ on failure for the internal pressure tests [27]. Thus, the change in effective surface area of the mini pipe during axial loading and pressure / combined load tests was negligible due to material toughness demonstrated particularly in the mechanical load tests [27]; thus, the use of the same surface areas would not alter the conclusions of the electrochemical test results.

The general trend of the effect of loading on the polarisation curves for the specimens tested in $3.5 \mathrm{wt} \% \mathrm{NaCl}$ plus 100 ppmw ammonium bisulphite is similar to that for specimens tested 
in $3.5 \mathrm{wt} \% \mathrm{NaCl}$ without ammonium bisulphite (Figure 10a). However, the corrosion potential for $3.5 \mathrm{wt} \% \mathrm{NaCl}$ plus $100 \mathrm{ppmw}$ ammonium bisulphite shifted more in the noble direction with application of load and the potential range corresponding to the passive region increased when compared with $3.5 \mathrm{wt} \% \mathrm{NaCl}$ without ammonium bisulphite. The pitting potentials for two nominally identical mini pipes subject to axial tension only in $3.5 \mathrm{wt} \%$ $\mathrm{NaCl}$ plus 100 ppmw ammonium bisulphite were $511 \mathrm{mV}_{\mathrm{Ag} \mid \mathrm{AgCl}}$ and $491 \mathrm{mV}_{\mathrm{Ag} \mid \mathrm{AgCl}}$; these are not significantly different from the pitting potentials of $503 \mathrm{mV}_{\mathrm{Ag} \mid \mathrm{AgCl}}$ and $520 \mathrm{mV}_{\mathrm{Ag} \mid \mathrm{AgCl}}$ for two identical specimens subject to combined load. Thus, the addition of 100 ppmw ammonium bisulphite to the $3.5 \mathrm{wt} \% \mathrm{NaCl}$ does not seem to have a detrimental effect on pitting resistance.

The $\log (i)-E$ plot for the tests in $3.5 \mathrm{wt} \% \mathrm{NaCl}$ plus $500 \mathrm{ppmw}$ is shown in Figure $10 \mathrm{~b}$. There was an indication of metastable pitting, initial pit growth (current density briefly exceeded $100 \mu \mathrm{A} / \mathrm{cm}^{2}$ ), and temporary repassivation before continuous pit growth when the SDSS pipes were subjected to load in both solutions. Unlike the $3.5 \mathrm{wt} \% \mathrm{NaCl}$ plus 100 ppmw ammonium bisulphite, when external load is applied to the SDSS mini pipes in 3.5 wt $\% \mathrm{NaCl}$ plus 500 ppmw and 1000 ppmw ammonium bisulphite, the interaction between ion dissolution and the passive film in addition to the formation of sulphide (protective) at pit initiation sites lead to a decrease in pitting resistance due to increased ammonium bisulphite concentration and a synergistic effect with chloride which reduces the $\mathrm{pH}$. An overview of the interaction between test environment and the iron that forms a significant part of the SDSS composition (Table 1) is provided in equation 2. 
$\mathrm{NH}_{4} \mathrm{HSO}_{3}+\mathrm{NaCl}+2 \mathrm{H}_{2} \mathrm{O}+5 \mathrm{Fe} \rightarrow \mathrm{NH}_{4} \mathrm{Cl}+\mathrm{NaS}+5 \mathrm{FeOH}$

The pitting potentials in $3.5 \mathrm{wt} \% \mathrm{NaCl}$ plus 500 ppmw ammonium bisulphite were 308 $\mathrm{mV}_{\mathrm{Ag} \mid \mathrm{AgCl}}$ and $304 \mathrm{mV}_{\mathrm{Ag} \mid \mathrm{AgCl}}$ for two nominally identical mini pipes subject to combined load, and $385 \mathrm{mV}_{\mathrm{Ag} \mid \mathrm{AgCl}}$ and $363 \mathrm{mV}_{\mathrm{Ag} \mid \mathrm{AgCl}}$ for two mini pipes subject to combined load in $3.5 \mathrm{wt} \% \mathrm{NaCl}$ plus $1000 \mathrm{ppmw}$ ammonium bisulphite. Similarly the pitting potential for the mini pipe subject to axial tension in $3.5 \mathrm{wt} \% \mathrm{NaCl}$ plus $500 \mathrm{ppmw}$ and $1000 \mathrm{ppmw}$ ammonium bisulphite respectively were $380 \mathrm{mV} \mathrm{Ag} \mid \mathrm{AgCl}_{1}, 321 \mathrm{mV}_{\mathrm{Ag} \mid \mathrm{AgCl}}$ and $359 \mathrm{mV} \mathrm{Ag} \mid \mathrm{AgCl}$, $316 \mathrm{mV}_{\mathrm{Ag} \mid \mathrm{AgCl}}$; for internal pressure only it was $376 \mathrm{mV}_{\mathrm{Ag} \mid \mathrm{AgCl}}, 406 \mathrm{mV}_{\mathrm{Ag} \mid \mathrm{AgCl}}$ and $372 \mathrm{mV}$ $\mathrm{Ag}|\mathrm{AgCl}, 332 \mathrm{mV} \mathrm{Ag}| \mathrm{AgCl}_{\text {r }}$ respectively. Thus, the increase in the concentration of ammonium bisulphite to $500 \mathrm{ppmw}$ and $1000 \mathrm{ppmw}$ had a similar detrimental effect on pitting resistance.

The effect of ammonium bisulphite and external load on the average pitting potential is shown in Figure 11. The average pitting potential for the mini pipes subject to only axial tension was not significantly different from that subject to combined load for all the various concentration of ammonium bisulphite considered (see Figure 11). The load in the axial tension test was within the elastic limit but when internal pressure was additionally applied the pipe was stressed beyond elastic limit but below the axial tension - internal pressure combination required for failure [27]; thus, the pipe with induced plastic deformation was more susceptible to pitting.

The $\mathrm{pH}$ of the $3.5 \mathrm{wt} \% \mathrm{NaCl}$ solution without ammonium bisulphite measured at $25{ }^{\circ} \mathrm{C}$ was 7 while the $\mathrm{pH}$ was between 4.5 and 5.5 with the addition of varying concentration of 
ammonium bisulphite (see Table 3). It was not possible to measure the $\mathrm{pH}$ of the bulk solution in situ at the test temperature $\left(90^{\circ} \mathrm{C}\right)$ due to electrode temperature limit $\left(50^{\circ} \mathrm{C}\right)$. Although, the $\mathrm{pH}$ of the bulk solution will decrease slightly with increase in temperature from ambient to $90{ }^{\circ} \mathrm{C}$, there is evidence to suggest that $E p$ of stainless steel is independent of $\mathrm{pH}$ below 8.5 of the bulk solution [34]. Turnbull and Ferriss found a decrease in $\mathrm{pH}$ in cracks in $3.5 \mathrm{wt} \% \mathrm{NaCl}$ compared to the $\mathrm{pH}$ of the bulk solution [31]. Although there is no measured data of $\mathrm{pH}$ inside the pits from the current series of tests, based on published results for low alloy steel [35], the $\mathrm{pH}$ inside the pits for the SDSS pipes is expected to be lower than the $\mathrm{pH}$ of the bulk solution which sustains further corrosion activity and pit growth.

In the reference test (no stress applied), the pipe relies mainly on the passive film for protection from corrosion. However, when load is applied there will be some dissolution of iron (Fe), chromium (Cr) etc. According to Pourbaix [36], all sulphur substances with oxidation numbers between the extreme -2 (sulphides) and +6 (sulphates), except for solid sulphur (oxidation number 0 ), are thermodynamically unstable and tend to decompose; thus sulphite (oxidation number +4 ) is unstable in water. In addition, ammonium bisulphite is a reducing agent and functions mainly as passivating corrosion inhibitor in addition to scavenging of oxygen [10]. Hemmingsen et al. [37] found that sulphide films are formed on carbon steel in sulphite solutions. Thus, it appears that in the tests where external load is applied the interaction between ion (primarily $\mathrm{Fe}$ and $\mathrm{Cr}$ ) dissolution (due to the stress stabilisation process) and the passive film, in addition to the formation of sulphide protective film, at pit initiation sites initially leads to an increase in pitting resistance at low ammonium

$$
\text { Wiley }-21 \mathrm{CH}
$$


bisulphite concentration. However, as the concentration increases beyond $100 \mathrm{ppmw}$ the presence and increase in sulphide leads to a decrease in pitting resistance.

\begin{abstract}
Ammonium bisulphite enhances the cathodic reaction which is consequently balanced by the anodic reaction, since the increase in ammonium bisulphite concentration in the $3.5 \mathrm{wt} \%$ $\mathrm{NaCl}$ solution causes $E_{\text {corr }}$ of the SDSS mini pipe to shift to a more negative potential. This implies that the ammonium bisulphite polarises the cathodic reaction and thus acts as a cathodic inhibitor for the pipe thereby decreasing the rate of hydrogen evolution and SCC of the SDSS pipes. However, at pit initiation sites the activity of the anodic reaction will produce hydrogen that gets absorbed in SDSS pipe as the presence of sulphide inhibits the recombination of atomic hydrogen $\left(\mathrm{H}^{+}\right)$. The atomic hydrogen recombines within the SDSS pipe microstructure to molecular hydrogen $\left(\mathrm{H}_{2}\right)$ leading to crack initiation.
\end{abstract}

Hydrogen ion concentration is a measure of $\mathrm{pH}$; the higher the hydrogen ion concentration, the lower the $\mathrm{pH}$. As the $\mathrm{pH}$ decreases, corrosion activity increases [16]. Thus, as the sulphite concentration in the solution $(3.5 \mathrm{wt} \% \mathrm{NaCl})$ increases the $\mathrm{pH}$ of the solution slightly decreases (Table 3). The resistance of the SDSS pipes to pitting increased with the addition of 100 ppmw ammonium bisulphite to $3.5 \mathrm{wt} \% \mathrm{NaCl}$ but decreased with further additions of ammonium bisulphite (500 and 1000 ppmw) when subject to various load conditions (axial tension, internal pressure and combined loading), see Figure 11. This suggests that the diffusion and migration processes of bisulphite / chloride ions have more of an effect on passive film growth and pit chemistry of the SDSS pipes in this environment when subjected to stress. The change in the surface stress is a key factor in the initiation of Wiley $-22 \mathrm{CH}$ 
pits [38]. Fatah et al. [39] found that the sulphide ions are easily adsorbed on mild steel surface, by occupying active sites on the steel surface, thereby accelerating the rate of steel dissolution. Thus, the optimum concentration for maximum resistance of the SDSS pipe under the various load conditions as illustrated in Figure 11 is 100 ppmw ammonium bisulphite.

In comparison to the reference (no external load), the pitting resistance was affected more by internal pressure than combined load in $3.5 \mathrm{wt} \% \mathrm{NaCl}$ and $3.5 \mathrm{wt} \% \mathrm{NaCl}$ plus $100 \mathrm{ppmw}$ ammonium bisulphite solution, while there was negligible effect of external loading on the pitting corrosion behaviour of the SDSS pipes in $3.5 \mathrm{wt} \% \mathrm{NaCl}$ plus $500 \mathrm{ppmw}$ and 1000 ppmw ammonium bisulphite. It seemed the ammonium bisulphite concentration was high enough to provide a protective film on the surface of the pipe thereby produce similar resistance quantitatively.

\subsection{Scanning electron microscope (SEM) observation}

Careful SEM examination of the surface of the pipe after anodic polarisation confirmed that the increase in current density was due to initiation of pits. Individual pits and sometimes cluster of pits and cracks were observed. Pits were observed on all the mini pipes exposed to the different solutions with or without external load. The pit morphology on the external surface of SDSS pipes were similar in all the environment considered however the pits tend to be less frequent with the addition of ammonium bisulphite to the sodium chloride solution (Figure 12). This observation implies that the ammonium bisulphite works as a passivating inhibitor which reduces the number of pit initiation sites. 
In the anodic potentiodynamic tests, the current output provided information on the growing pits as the applied potential increased. As ammonium bisulphite concentration increased the number of pits initiated was less; thus, the cathodic current increased and was balanced by the increase in anodic current resulting in increased pit growth (associated with hydrogen evolution within the pit and further acidification) at discrete points. The hydrogen produced by the electrochemical reaction may readily diffuse into the metal structure with consequent detrimental effect on the mechanical strength and ductility of the metal.

The pits on the external surface of the SDSS pipes in sodium chloride solution (without ammonium bisulphite) contained little or no deposits while the pits on the pipes tested in sodium chloride plus various concentration of ammonium bisulphite usually contained corrosion deposits. The amount of deposits appeared to increase with increasing ammonium bisulphite concentration (Figure 13). The presence of deposits will facilitate pit growth. Ernst and Newman [40] found precipitation of metal salt takes place (at the pit bottom) and the pit grows underneath the salt film at a rate controlled by the dissolution of this film and local concentration gradient. It is expected that the addition of ammonium bisulphite to the sodium chloride solution will have more of an effect on the concentration gradient of the bulk solution and pit interior compared to sodium chloride solution due to the type of deposits in the pits.

Visual examination of the deposit suggests the pits on the pipes tested in $3.5 \mathrm{wt} \% \mathrm{NaCl}$ solution contained sodium chloride salt deposit while the pits on pipes tested in sodium 
chloride / ammonium bisulphite contained a mixture of sodium chloride and ammonium salts.

Although pits were identified on the surface of most of the samples tested under external load, only SDSS pipes subject to internal pressure or combined load showed any signs of crack initiation from the pits which formed during the electrochemical tests (Figure 14). The polishing marks that are visible in Figure 14 are parallel to the hoop direction, and cracks which initiated from the pits appear to grow perpendicular to the hoop direction. The surface finish of the mini pipe was higher than the surface finish required for test samples in standards for four-point bend, $\mathrm{C}$ ring and tensile samples i.e. 0.7 [41], 0.7 [42] and $0.25 \mu \mathrm{m}$ [43] respectively. The wall thickness was machined to within $0.2 \mu \mathrm{m}$ tolerance to ensure that the wall thickness of the mini pipes $(0.25 \mathrm{~mm})$ were consistent as confirmed by the failure loads test results compared to theory (Figure 6). Thus, a higher surface finish (compared to standard test samples) was accepted for the mechanical and corrosion tests. The surface finish did not affect the mechanical [27] or corrosion tests as test results were consistent as illustrated in the failure envelope test and polarisation results (Figure 9). Furthermore, the surface finish did not affect the crack initiation and orientation. Rajaguru and Arunachalam in their investigation on machining induced surface and subsurface modifications on the SCC growth behavior of SDSS found clusters, parallel and perpendicular cracks [44]. Only perpendicular cracks were found during SEM investigation of the mini pipes. The pipe was closed at one end (Figure 3) and pressurised through the other (Figure 5). Three load cases were considered: axial tensile stress of $568 \mathrm{MPa}\left(=0.64 \sigma_{0.2}\right)$; internal pressure of $48.3 \mathrm{MPa}$, which induced a hoop stress of $773 \mathrm{MPa}$ in the pipe; and a combined axial stress of $568 \mathrm{MPa}$ and hoop stress of $773 \mathrm{MPa}$. The major principal stress for internal pressure and combined 
loading conditions was the hoop stress. Based on maximum principal stress failure criterion, crack initiation and growth occur perpendicular to the maximum principal stress. The observed direction of crack growth is consistent with the maximum principal stress criterion. The internal pressure applied in the current tests was based on 0.85 times the measured burst pressure at $90{ }^{\circ} \mathrm{C}$. This indicates that the SDSS pipes under internal pressure or combined axial tension and internal pressure are susceptible to SCC in the various test environments. Thus, the internal pressure of $48.3 \mathrm{MPa}$ in the mini SDSS pipes considered in this study exceeded the threshold for initiation of SCC in the test environment. Cracks will initiate and grow from a pit as pits introduce local stress concentration which promotes crack growth and affects the effectiveness of the passive film and inhibitor (ammonium bisulphite) films as a barrier to mitigate further corrosion.

The mini pipes subject to axial tension and those with no external load (i.e. reference specimen) exhibited only pitting in all test environments as confirmed by the SEM images. The stresses in both tests were within the elastic limit of the SDSS pipes and yield stress at room temperature and test temperature are similar (Table 2); thus, as expected, the environment effect was more significant, as the corrosivity (decrease in $\mathrm{pH}$ ) increases (illustrated by potentiodynamic tests). In the group of mini pipes which were under combined loading the stress level was always beyond the elastic limit of the material. In such circumstance not only were pits observed there was also initiation of cracks. This confirms a stress effect and susceptibility to cracking in all test environments for pipes subject to combined loading. In the test environments considered in this study it is expected that crack initiation could be prevented by lowering the applied internal pressure to $40 \mathrm{MPa}$; this is the

$$
\text { Wiley } 26 \mathrm{CH}
$$


pressure when the pressure versus hoop strain response changes from being linear to nonlinear [27]. The threshold load for SCC initiation in the SDSS pipe under internal pressure and combined load requires further investigation.

\section{CONCLUSIONS}

The corrosion behaviour of $25 \mathrm{Cr}$ SDSS mini pipe subject to axial tension, internal pressure, and combined load (axial tension and internal pressure) was investigated in $3.5 \mathrm{wt} \% \mathrm{NaCl}$ solution with various concentration of ammonium bisulphite $(0,100,500$ and 1000 ppmw) and at a temperature of $90^{\circ} \mathrm{C}$. The external surface of the mini pipe was exposed to the test environment, the corrosion potential versus current density measurements was determined. From the experimental results obtained from this study, the following conclusions can be made:

1. Pitting was observed under all exposure conditions on the external surface of the pipe. However, the addition of ammonium bisulphite was found to reduce the density of pits and to increase the severity of the remaining pits left on the surface of the pipe. The presence of chlorides is a key component in the pitting of the external surface of the SDSS mini pipes at $90{ }^{\circ} \mathrm{C}$. The increase in chloride from 0.1 to 1 and to $3.5 \mathrm{wt} \%$ and the addition of ammonium bisulphite generally resulted in increased active values for the corrosion potential and decreased the pitting resistance. The resistance of the SDSS pipes to pitting when subject to various load conditions (combined axial tension and internal pressure, axial tension and internal pressure) increased slightly with the addition of 100 ppmw ammonium bisulphite to $3.5 \mathrm{wt} \%$ $\mathrm{NaCl}$ but decreased with further additions of ammonium bisulphite (500 and 1000

$$
\text { Wiley }-27 \mathrm{CH}
$$


ppmw). Thus, the optimum concentration for maximum resistance of the SDSS pipe to pitting corrosion under the various load conditions is $100 \mathrm{ppmw}$ ammonium bisulphite in $3.5 \mathrm{wt} \% \mathrm{NaCl}$.

2. The pitting resistance of the SDSS pipe was found to be affected more by internal pressure than combined load in $3.5 \mathrm{wt} \% \mathrm{NaCl}$ and $3.5 \mathrm{wt} \% \mathrm{NaCl}$ plus $100 \mathrm{ppmw}$ ammonium bisulphite solution. The pitting potentials of the mini pipes subjected to axial tension, combined axial tension and internal pressure in $3.5 \mathrm{wt} \% \mathrm{NaCl}$ plus 500 ppmw and 1000 ppmw ammonium bisulphite were quite similar; the pitting resistance of the SDSS pipe in both solutions under the same loading condition were less than in the $3.5 \mathrm{wt} \% \mathrm{NaCl}$ and $3.5 \mathrm{wt} \% \mathrm{NaCl}$ plus $100 \mathrm{ppmw}$ ammonium bisulphite solution.

3. Crack initiation from pits was observed in specimens subjected to internal pressure and combined internal pressure and axial tension, while none was observed in specimens, subject to only axial tension. The internal pressure applied was 0.85 and 0.72 of the burst pressure at $90^{\circ} \mathrm{C}$ and room temperature respectively. Therefore, the internal pressure of 48.3 MPa exceeds the threshold for initiation of SCC in the test environment considered in this study.

\begin{abstract}
Material selection for production tubings used in oil and gas well completions is based on qualification (corrosion) tests in relevant environments usually from test samples subject to simple mode loading. Material selection for production tubing used in well completions
\end{abstract}


requires an understanding of the relationship between service stresses caused by load (weight of tubing string) and pressure and the ability of the material to resist crack initiation in service. Therefore, rather than conventional test samples, the use of mini pipes is proposed to better define application limits in corrosive environments either by potentiodynamic tests and/or immersion tests once the failure envelope is determined in the absence of any corrosive environment.

\section{ACKNOWLEDGEMENTS}

The financial support of Shell UK is acknowledged. The authors would like to thank the following technical staff, Stuart Herbert, Alistair Robertson for the machining of the mini pipes, Derek Logan and Irene Brand for resolving several electrical issues and providing accessories, and Jim Gall for help with the test set-up and prompt supply of tools and equipment. 


\section{REFERENCES}

[1] A. Turnbull, S. Zhou, Corr. Sci. 2004, 46, 1239.

[2] A. Turnbull, L. N. McCartney, S. Zhou, Corr. Sci. 2006, 48, 2084.

[3] J. Oredsson, S. Bernhardsson, Material Performance, 1983, 1, 34.

[4] H. Tsuge, The Sumitomo Search, 1988, 5, 65.

[5] L. Cao, A. Anderko, F. Gui, N. Sridhar, Corrosion, 2016, 72, 636.

[6] E. Mazario, R. Venegas, P. Herrasti, M.C. Alonso, F.J. Recio, Journal of Solid State Electrochemistry, 2016, 20, 1223.

[7] D. E. Mowat, M.C. Edgerton, E. H. R. Wade, presented at SPE/IADC Drilling Conference, Amsterdam, Netherlands, 27 February - 1 March, 2001, Paper No. 67779.

[8] R. Mack, C. Williams, S. Lester, J. Casassa, presented at Corrosion 2002, Denver, Colorado, USA, 7 - 11 April, 2002, Paper No. 2067.

[9] I. M. Hannah, D. A. Seymour, presented at Corrosion 2006, San Diego, California, USA, 12 - 16 March, 2006, Paper No. 06491.

[10] NACE International Task Group T-3A-6, Oxygen Scavengers in Steam Generating Systems and in Oil Production, NACE Item No. 24177, 1994.

[11] B. A. Lasebikan, A. R. Akisanya, W. F. Deans, D. E. Macphee, Corr. Sci. 2011, 53, 4014.

[12] N. Zhou, R. Pettersson, R. Lin Peng, M. Schonning, Materials Science and Engineering, 2016, 658, 50 . 
[13] H. P. Seifert, R. Ritter, Corr. Sci. 2016, 108, 134.

[14] L. Wickstrom, K. Mingard, G. Hinds, A. Turnbull, Corr. Sci. 2016, 109, 86.

[15] J. Soltis, Corr. Sci. 2015, 90, 2.

[16] A. Keitelman and M. G. Alvarez, Corrosion, 2017, 73, 8.

[17] E Hornlund, J.K.T. Fossen, S, Hauger, C. Haugen, T. Havn, T. Hemmingsen, Int. J. of Electrochem. Sci., 2007, 2, 82.

[18] B. A. Lasebikan, A. R. Akisanya, W. F. Deans, J. Materials Engineering and Performance, 2013, 22, 598.

[19] H. Hanninen, J. Romu, R. Ilola, J. Tervo, and A. Laitinen, J. Mater. Proc. Tech., 2001, $117,424$.

[20] J. Airao, B. Chaudhary, V. Bajpai, N. Khanna, Materials Today: Proceedings, 2018, 5, 3682.

[21] ASTM G48-03, Standard Test Methods for Pitting and Crevice Corrosion Resistance of Stainless Steels and Related Alloys by Use of Ferric Chloride Solution, 2003.

[22] X. Xu, M. Zhao, Y. Feng, F. Li, X. Zhang, Int. J. Electrochem. Sci., 2018, 13, 4298.

[23] G. Chail, P. Kangas, Procedia Structural Integrity, 2016, 2, 1755.

[24] ASTM G5-94 (Reapproved 2004), Standard reference test method for making potentiostatic and potentiodynamic anodic polarisation measurements, 2004.

[25] B. A. Lasebikan, A. R. Akisanya, W. F. Deans, J. Eng. Design and Technology, 2015, 13,539 . 
[26] ASTM G150-99 (Reapproved 2004), Standard Test Method for Electrochemical Critical Pitting Temperature Testing of Stainless Steel, 2004.

[27] B.A. Lasebikan, A.R. Akisanya, Int. J. Pres. Vessel and Piping, 2014, 119, 62.

[28] U. Obi, Ph. D. Thesis, University of Aberdeen, 2015.

[29] L. He, Y-J. Guo, X. -Y, Wu, Y. -M. Jiang, J. Li, J. of Iron and Steel Research International, 2016, 23, 357.

[30] G. Hinds, L. Wickstrom, K. Mingard, A. Turnbull, Corr. Sci. 2013, 71, 43.

[31] K. van Gelder, J. G. Erlings, J. W. M. Damen, A. Visser, Corr. Sci. 1987, 27, 1271.

[32] S. T. Tsai, K. P. Yen, H. C. Shih, Corr. Sci. 1998, 40, 281.

[33] N.C. Renton, A.M. Elhoud, W.F. Deans, J. of Mater. Engineering and Performance, 2011, 20, 436.

[34] B. Tzaneva, J. Chem. Tech. Metall. 2013, 48, 383-390.

[35] A. Turnbull, D. H. Ferriss, Corr. Sci. 1987, 27, 1323.

[36] M. Pourbaix, Atlas of electrochemical equilibria in aqueous solutions, Pergamon Press Ltd. Great Britain, 1966.

[37] T. Hemmingsen, F. Fusek, E. Skavås, Electrochimica Acta, 2006, 51, 2919.

[38] V. Vignal, O. Delrue, O. Heintz, J. Peultier, Electrochimica Acta, 2010, 55, 7118.

[39] M. C. Fatah, M. C. Ismail, B. Ari-Wahjoedi, K. A. Kurnia, Material Chemistry and Physics, 2011, 127, 347.

[40] P. Ernst, R. C. Newman, Corr. Sci. 2002, 44, 927.

$$
\text { Wiley } 32 \mathrm{CH}
$$


[41] ASTM G39-99, (Reapproved 2005). Standard practice for preparation and use of bent beam, stress-corrosion test specimens, 2005.

[42] ASTM G38-01, Standard practice for making and using C-ring stress-corrosion test specimens, 2001.

[43] ASTM G129-00, Standard practice for slow strain rate testing to evaluate the susceptibility of metallic materials to environmentally assisted cracking, $\mathbf{2 0 0 0 .}$.

[44] J. Rajaguru, N. Arunachalam, Corr. Sci. 2018, 141, 230. 
Table 1- Pipe Chemical Composition percent by weight.

\begin{tabular}{|l|l|}
\hline Elements & wt\% \\
\hline Carbon & 0.02 \\
\hline Silicon & 0.036 \\
\hline Manganese & 0.049 \\
\hline Phosphorus & 0.026 \\
\hline Sulphur & $<0.015$ \\
\hline Chromium & 24.5 \\
\hline Molybdenum & 3.27 \\
\hline Nickel & 6.83 \\
\hline Copper & 0.49 \\
\hline Vanadium & 0.09 \\
\hline Cobalt & 0.11 \\
\hline Titanium & 2.61 \\
\hline Nitrogen & 0.32 \\
\hline Iron & Balance \\
\hline
\end{tabular}

Table 2 - The average uniaxial tensile properties of the $25 \mathrm{Cr}$ SDSS at room temperature $\left(18^{\circ} \mathrm{C}\right)$ and elevated temperature of $90^{\circ} \mathrm{C}$

\begin{tabular}{|l|c|c|}
\hline Temperature $\left({ }^{\mathbf{}} \mathbf{C}\right)$ & $\mathbf{1 8}$ & $\mathbf{9 0}$ \\
\hline Yield Stress $(\mathrm{MPa})$ & 601 & 601 \\
\hline $0.2 \%$ Proof Stress $(\mathrm{MPa})$ & 969 & 881 \\
\hline Tensile Strength $(\mathrm{MPa})$ & 1063 & 948 \\
\hline Young's Modulus $(\mathrm{GPa})$ & 208 & 207 \\
\hline
\end{tabular}


Table 3 - The $\mathrm{pH}$ and dissolved oxygen of the test solution containing different ammonium bisulphite concentration.

(a) $\mathrm{pH}$

\begin{tabular}{|l|c|c|c|c|}
\hline \multirow{2}{*}{ Solution } & \multicolumn{4}{|c|}{ Ammonium bisulphite concentration (ppmw) } \\
\cline { 2 - 5 } & $\mathbf{0}$ & $\mathbf{1 0 0}$ & $\mathbf{5 0 0}$ & $\mathbf{1 0 0 0}$ \\
\hline Deionised Water & 6.9 & 5.5 & 5.3 & 5.2 \\
\hline $1 \mathrm{wt} \% \mathrm{NaCl}$ & 6.8 & 5.2 & 4.9 & 4.9 \\
\hline $3.5 \mathrm{wt} \% \mathrm{NaCl}$ & 7.3 & 4.8 & 4.7 & 4.5 \\
\hline
\end{tabular}

(b) Dissolved oxygen (ppbw)

\begin{tabular}{|l|c|c|c|c|}
\hline \multirow{2}{*}{ Solution } & \multicolumn{4}{|c|}{ Ammonium bisulphite concentration (ppmw) } \\
\cline { 2 - 5 } & $\mathbf{0}$ & $\mathbf{1 0 0}$ & $\mathbf{5 0 0}$ & $\mathbf{1 0 0 0}$ \\
\hline Deionised Water & 4100 & 5740 & 5720 & 5990 \\
\hline $1 \mathrm{wt} \% \mathrm{NaCl}$ & 5390 & 5750 & 5830 & 5150 \\
\hline $3.5 \mathrm{wt} \% \mathrm{NaCl}$ & 4870 & 4440 & 4510 & 4100 \\
\hline
\end{tabular}

Table 4 - OCP and $E_{p}$ of the mini pipe in various test solutions (sodium chloride and ammonium bisulphite) with no loads applied. Results are shown for two nominally identical mini pipes, identified as $\mathrm{A}$ and $\mathrm{B}$. The values are in Volts relative to $\mathrm{Ag} \mid \mathrm{AgCl}$ reference electrode.

\begin{tabular}{|l|c|c|c|c|}
\hline \multirow{2}{*}{ Solution } & \multicolumn{2}{c|}{$\mathbf{A}$} & \multicolumn{2}{c|}{ B } \\
\cline { 2 - 4 } & OCP & $\boldsymbol{E}_{\boldsymbol{p}}$ & OCP & $\boldsymbol{E}_{\boldsymbol{p}}$ \\
\hline $0.1 \mathrm{wt} \% \mathrm{NaCl}$ & -0.148 & 0.469 & -0.156 & 0.586 \\
\hline $0.1 \mathrm{wt} \% \mathrm{NaCl}+100 \mathrm{ppmw}$ & -0.186 & 0.714 & -0.185 & 0.757 \\
\hline $0.1 \mathrm{wt} \% \mathrm{NaCl}+500 \mathrm{ppmw}$ & -0.184 & 0.723 & -0.182 & 0.705 \\
\hline $0.1 \mathrm{wt} \% \mathrm{NaCl}+1000 \mathrm{ppmw}$ & -0.203 & 0.693 & -0.203 & 0.695 \\
\hline $1 \mathrm{wt} \% \mathrm{NaCl}$ & -0.161 & 0.480 & -0.178 & 0.520 \\
\hline $1 \mathrm{wt} \% \mathrm{NaCl}+100 \mathrm{ppmw}$ & -0.379 & 0.259 & -0.386 & 0.289 \\
\hline $1 \mathrm{wt} \% \mathrm{NaCl}+500 \mathrm{ppmw}$ & -0.402 & 0.402 & -0.404 & 0.570 \\
\hline $1 \mathrm{wt} \% \mathrm{NaCl}+1000 \mathrm{ppmw}$ & -0.386 & 0.426 & -0.390 & 0.429 \\
\hline $3.5 \mathrm{wt} \% \mathrm{NaCl}$ & -0.152 & 0.458 & -0.160 & 0.484 \\
\hline $3.5 \mathrm{wt} \% \mathrm{NaCl}+100 \mathrm{ppmw}$ & -0.284 & 0.369 & -0.289 & 0.343 \\
\hline $3.5 \mathrm{wt} \% \mathrm{NaCl}+500 \mathrm{ppmw}$ & -0.298 & 0.332 & -0.292 & 0.349 \\
\hline $3.5 \mathrm{wt} \% \mathrm{NaCl}+1000 \mathrm{ppmw}$ & -0.304 & 0.423 & -0.312 & 0.405 \\
\hline
\end{tabular}




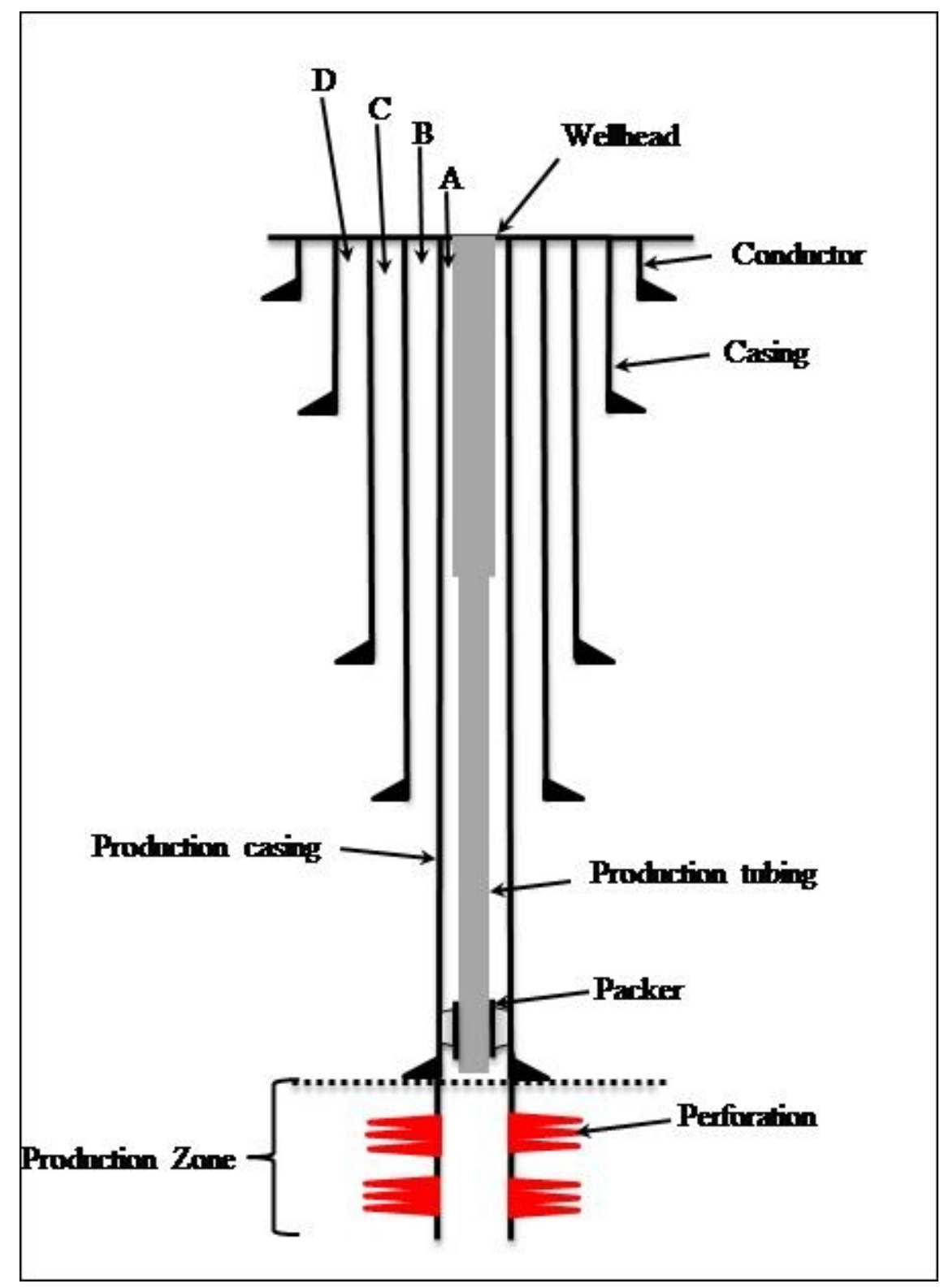

A schematic of a typical well completion system

$119 \times 164 \mathrm{~mm}(96 \times 96 \mathrm{DPI})$ 


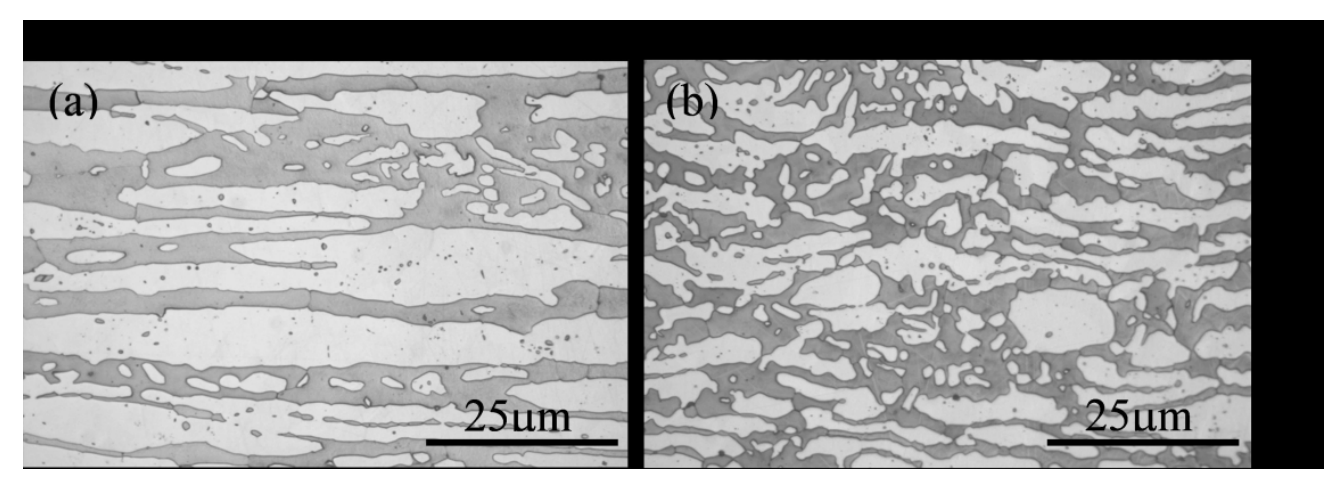

Microstructure of SDSS (a) longitudinal and (b) transverse direction $997 \times 343 \mathrm{~mm}(96 \times 96 \mathrm{DPI})$ 

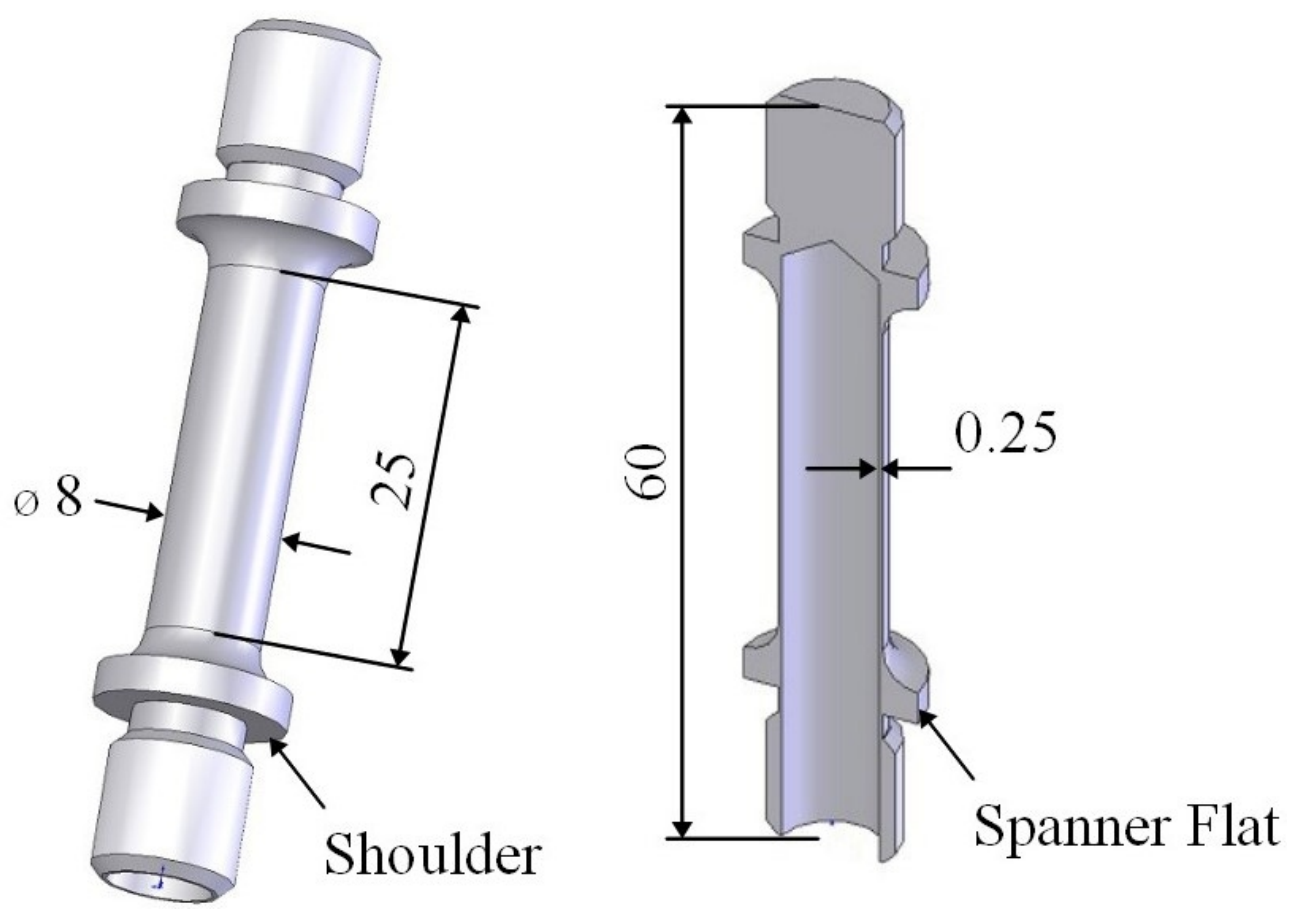

The mini pipe (all dimensions in $\mathrm{mm}$ )

$217 \times 150 \mathrm{~mm}(96 \times 96$ DPI $)$ 


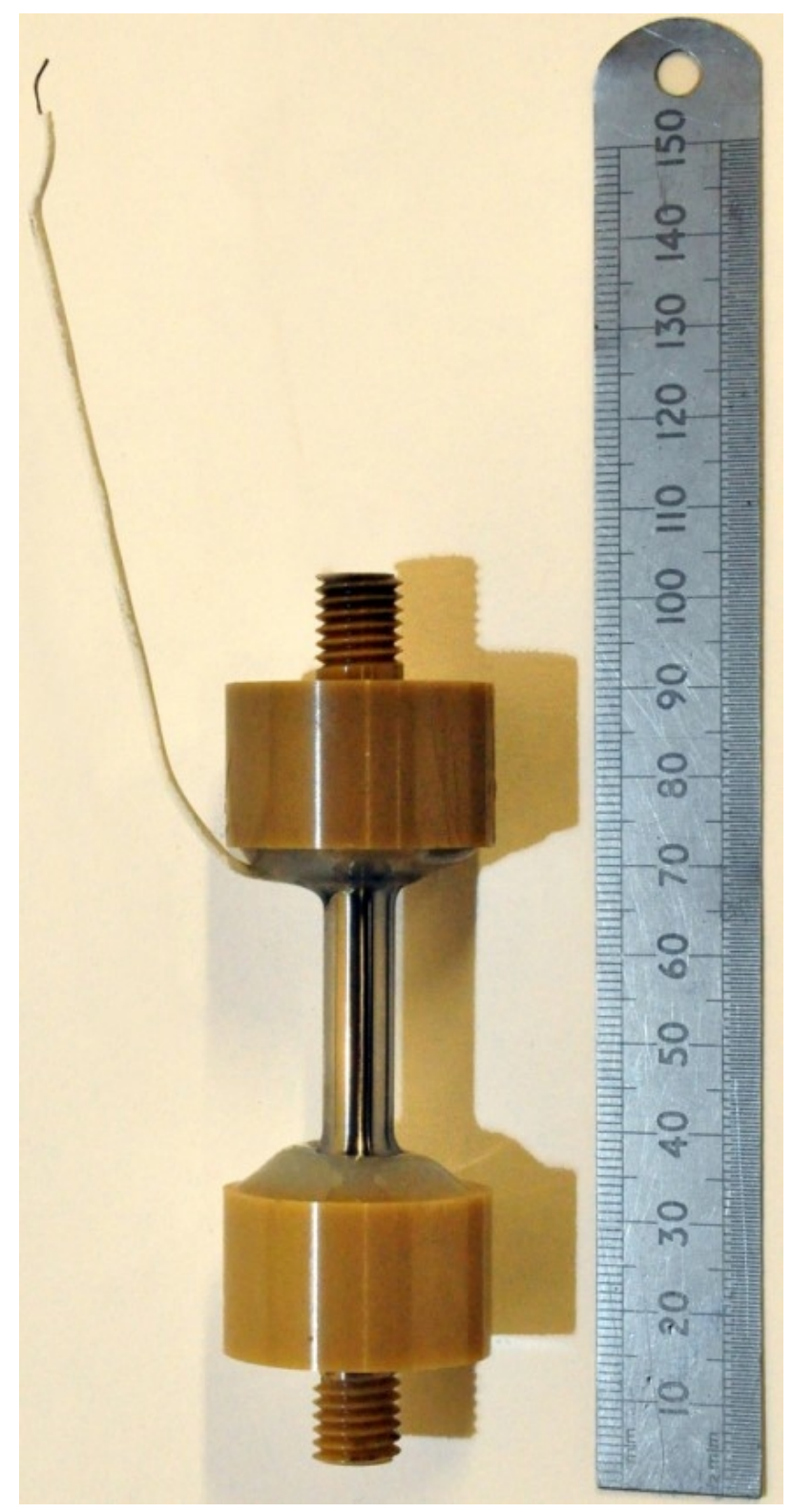

Mini pipe set-up for corrosion test $50 \times 98 \mathrm{~mm}(220 \times 220$ DPI $)$ 


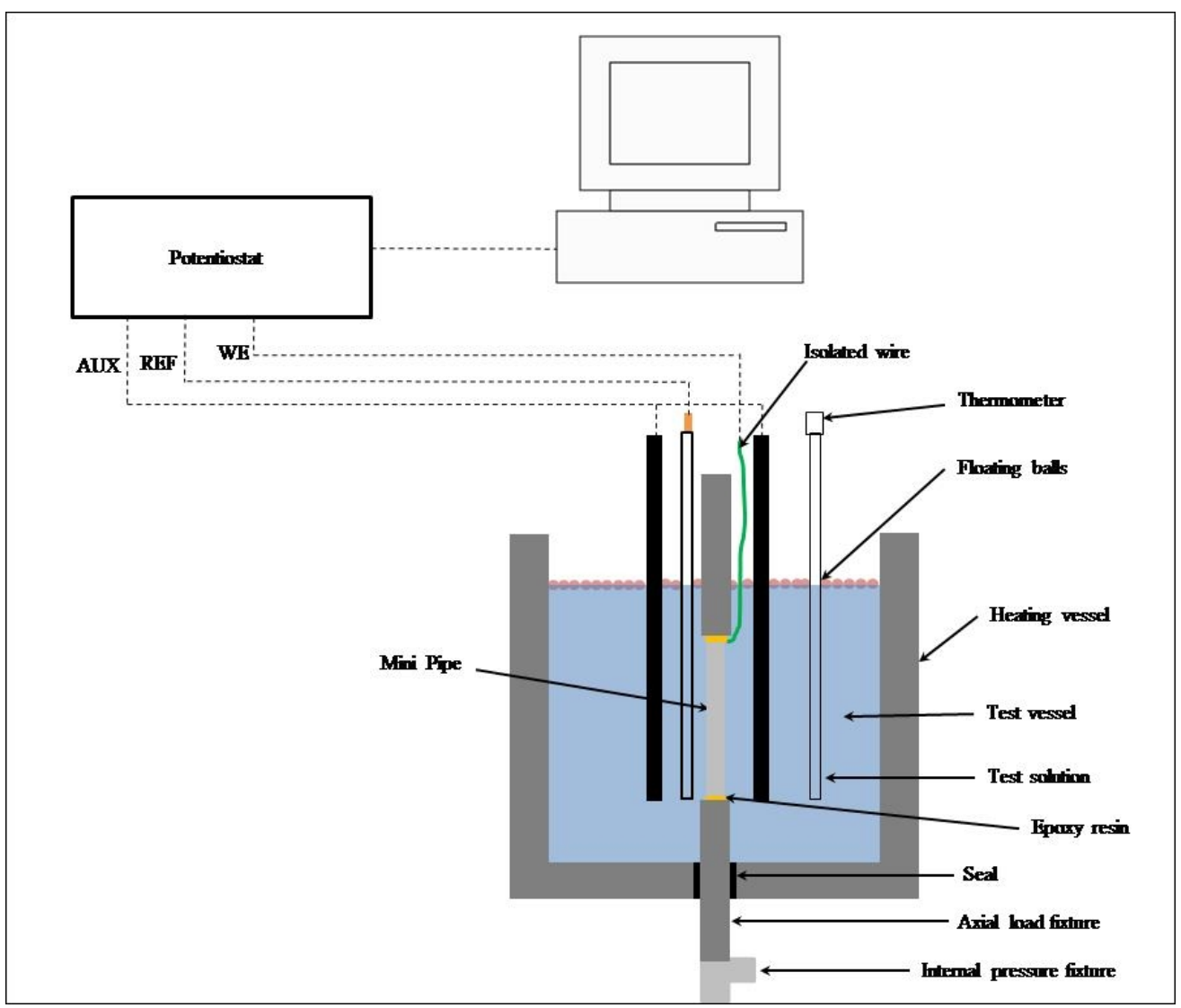

A schematic of the electrochemical polarisation test set-up $237 \times 201 \mathrm{~mm}(96 \times 96$ DPI) 


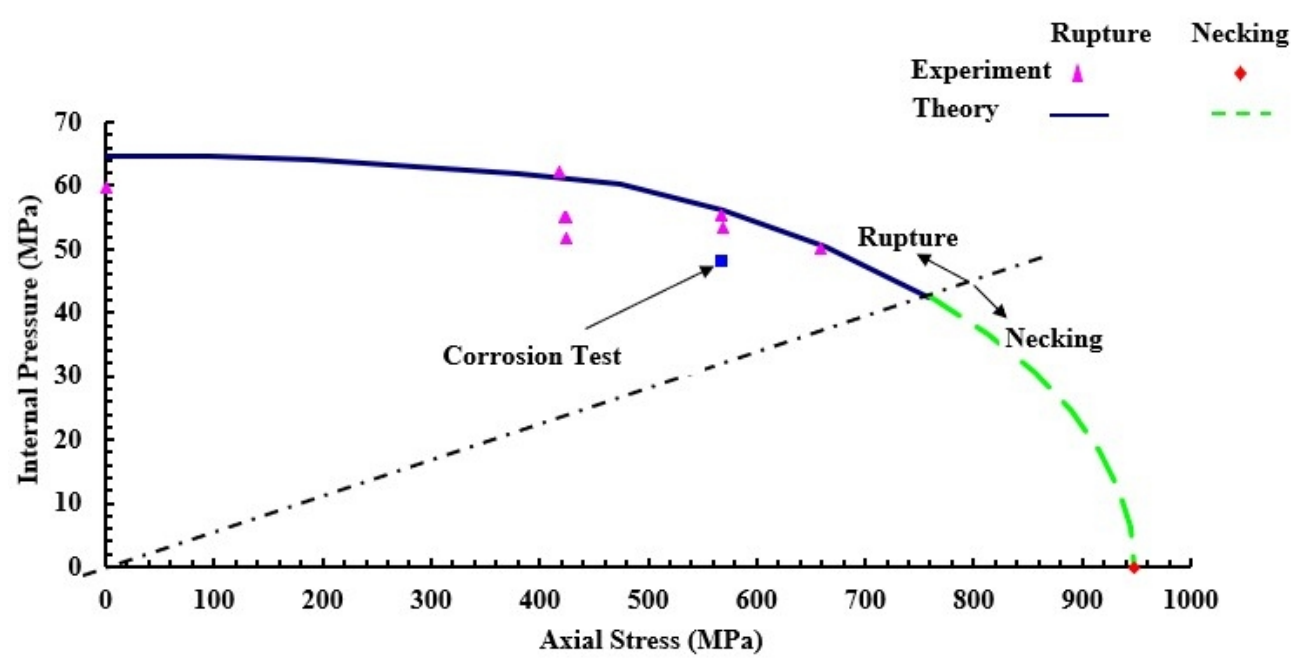

Corrosion test data point in mini pipe failure envelope at $90 \mathrm{oC}$

$197 \times 105 \mathrm{~mm}(96 \times 96 \mathrm{DPI})$ 


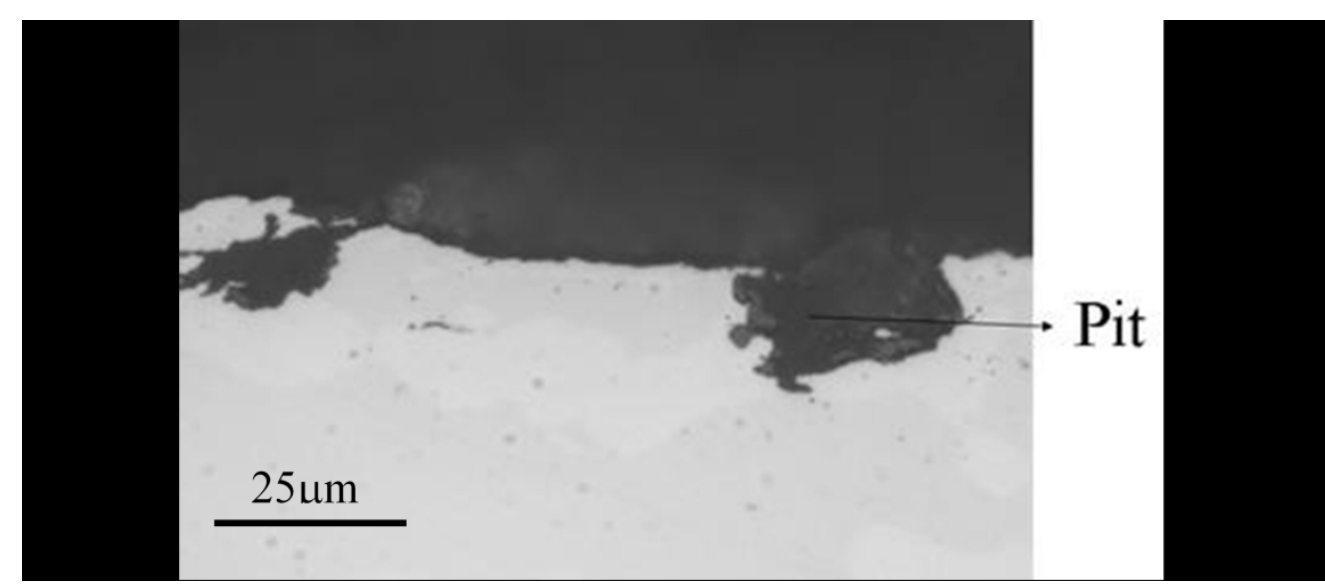

Micrograph of the cross-section of a pit after immersion test $997 \times 429 \mathrm{~mm}(96 \times 96 \mathrm{DPI})$ 

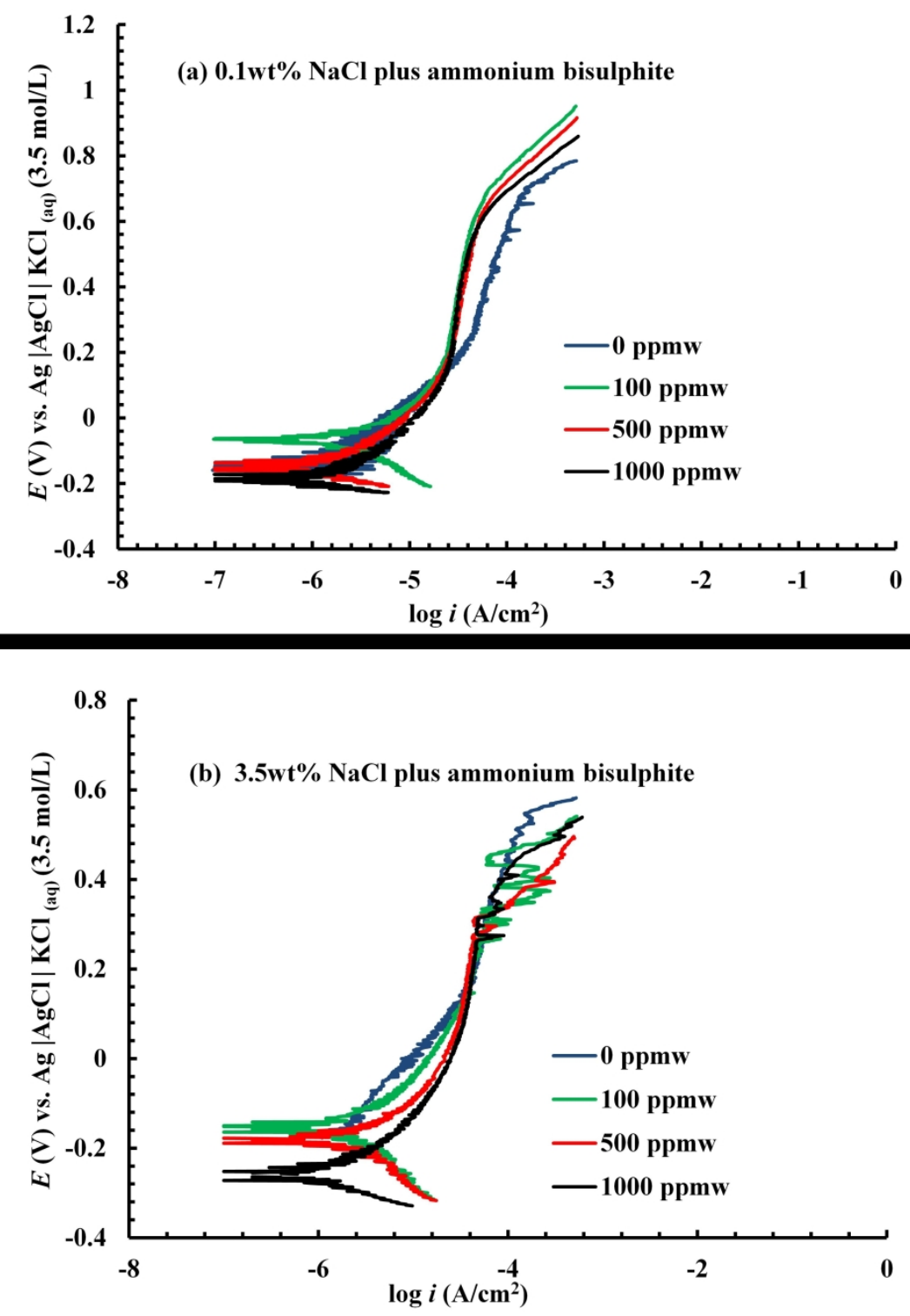

Polarisation scan of mini pipes for the reference tests where the mini pipes were not subjected to external load in (a) $0.1 w t \% \mathrm{NaCl}$ solution and (b) $3.5 \mathrm{wt} \% \mathrm{NaCl}$ solution

$$
1046 \times 1362 \mathrm{~mm}(96 \times 96 \mathrm{DPI})
$$



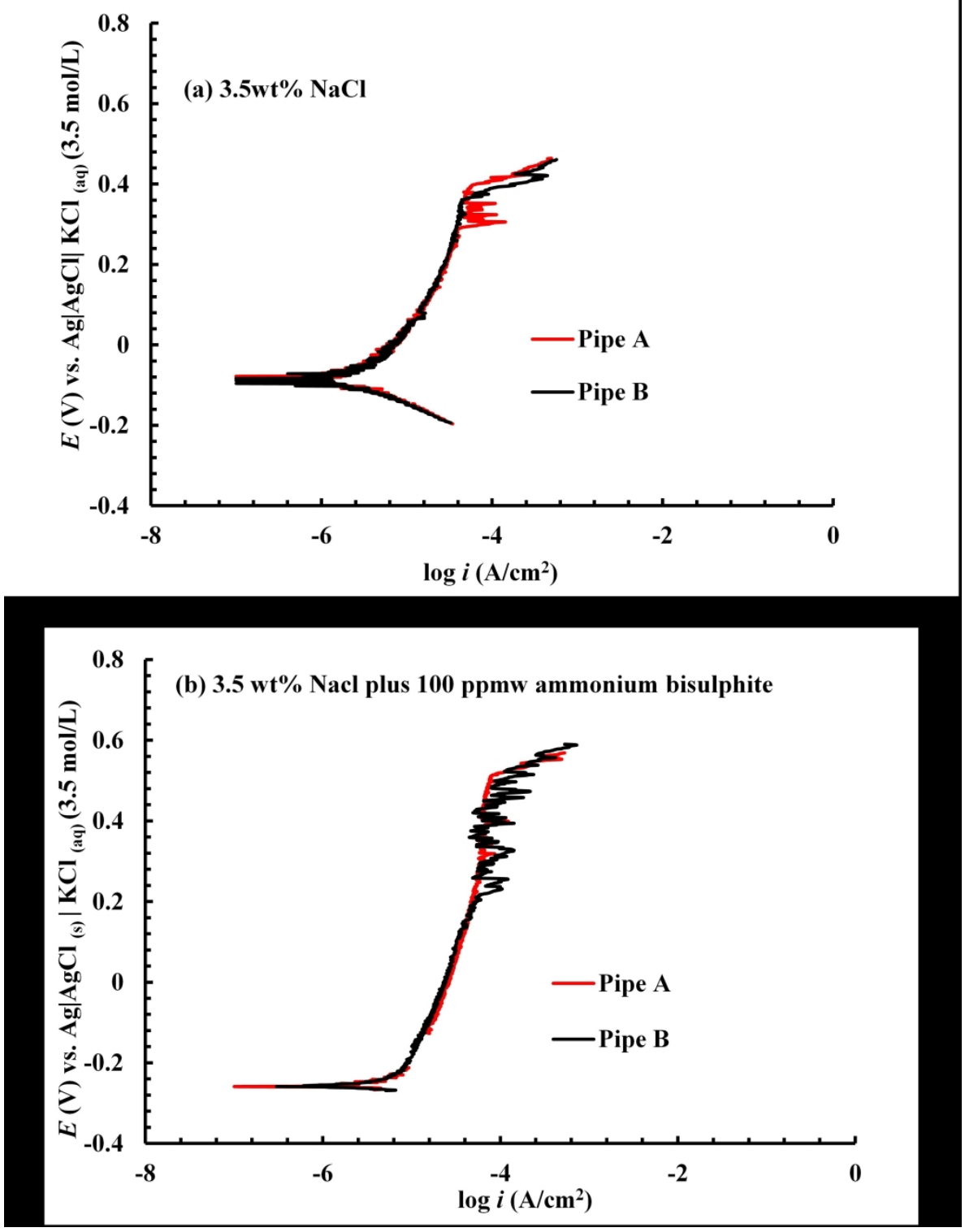

Polarisation scan of SDSS for two nominally identical mini pipes subject to combined axial tension and internal pressure at $90 \mathrm{oC}$ in (a) $3.5 \mathrm{wt} \% \mathrm{NaCl}$ solution and (b) $3.5 \mathrm{wt} \% \mathrm{NaCl}$ plus $100 \mathrm{ppmw}$ ammonium bisulphite

$998 \times 1322 \mathrm{~mm}(96 \times 96 \mathrm{DPI})$ 

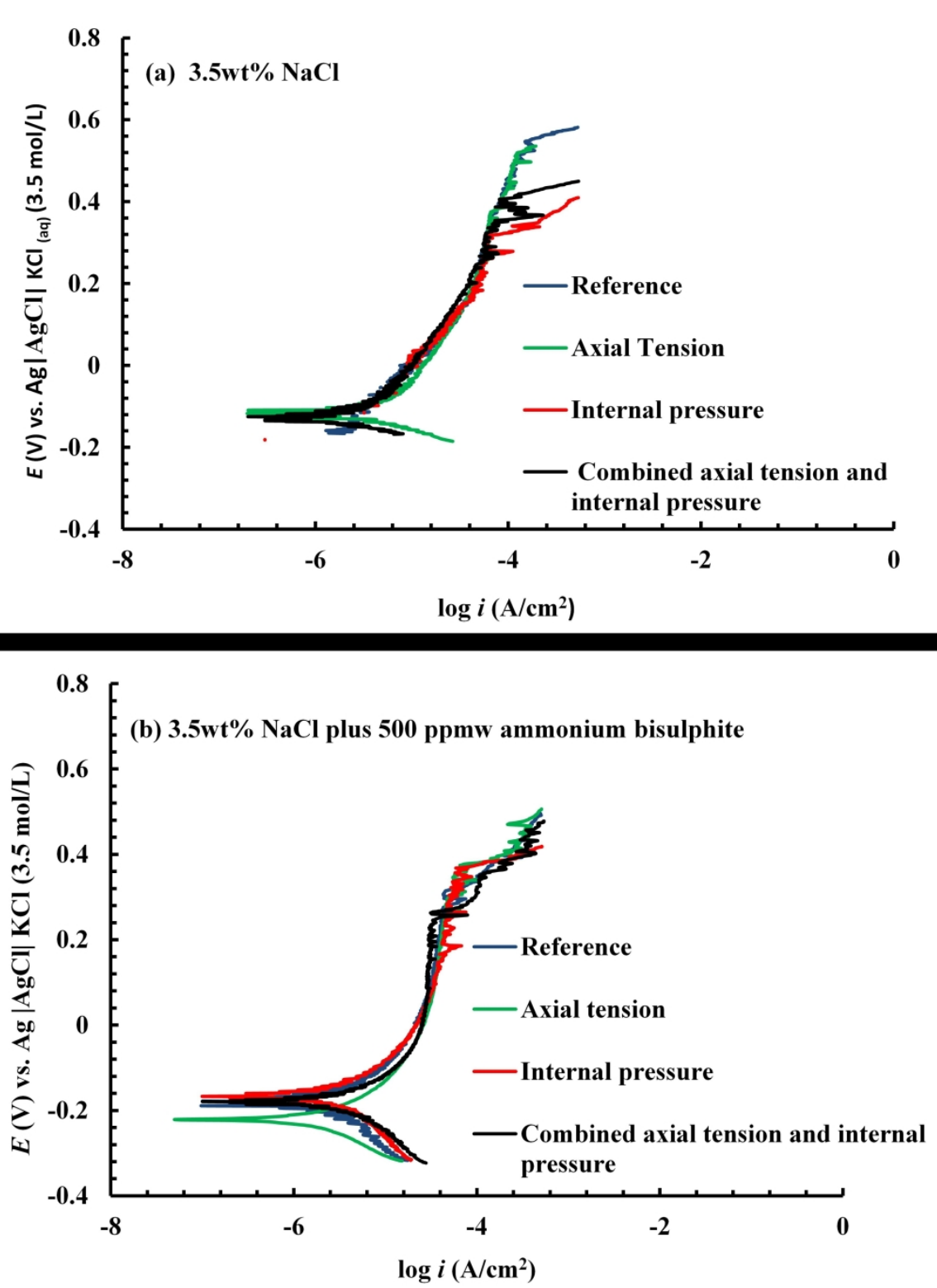

Effect of externally applied load on the polarisation scan of SDSS mini pipes exposed at 90 oC to $3.5 \mathrm{wt} \%$ $\mathrm{NaCl}$ solutions ( 0 ppmw and 500 ppmw ammonium bisulphite).

Figure 11 - The effect of external load and concentration of ammonium bisulphite in $3.5 \mathrm{wt} \% \mathrm{NaCl}$ on the pitting potential of SDSS at $90 \mathrm{oC}$

$$
1034 \times 1310 \mathrm{~mm}(96 \times 96 \mathrm{DPI})
$$


The effect of external load and concentration of ammonium bisulphite in $3.5 \mathrm{wt} \% \mathrm{NaCl}$ on the pitting potential of SDSS at $90 \mathrm{oC}$

$165 \times 107 \mathrm{~mm}(150 \times 150 \mathrm{DPI})$ 


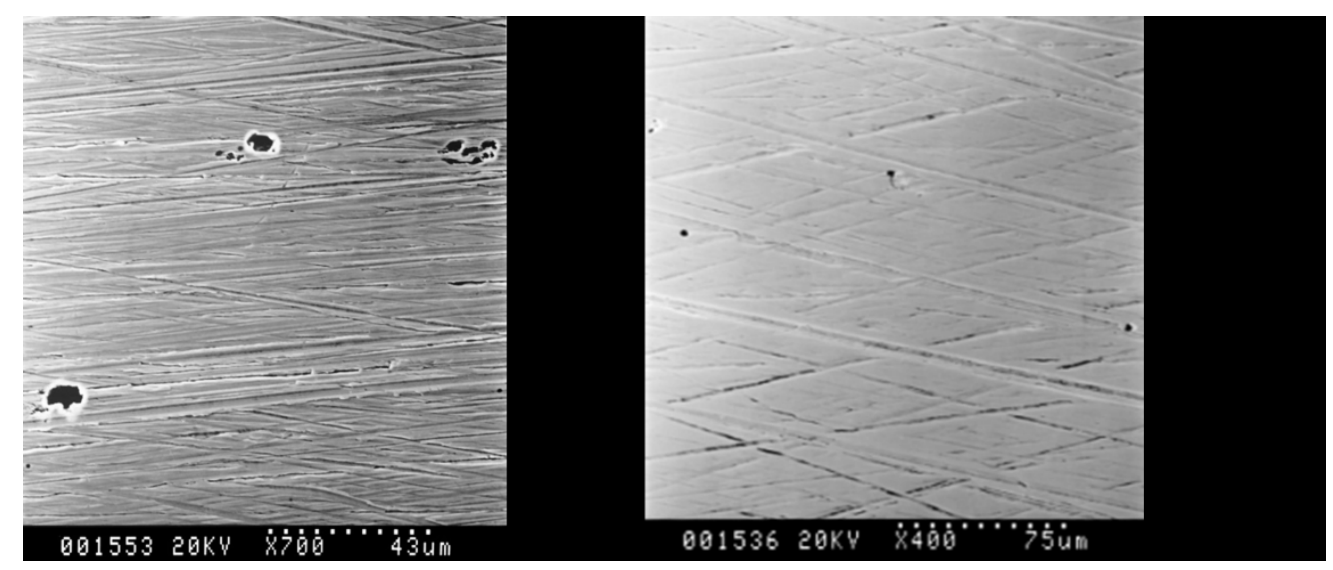

Effect of ammonium bisulphite addition to $3.5 \mathrm{wt} \% \mathrm{NaCl}$ at $90 \mathrm{oC}$ on the initiation of pits on the surface of the $25 \mathrm{Cr}$ SDSS mini pipe in (a) $3.5 \mathrm{wt} \% \mathrm{NaCl}$ and subject to axial load, and (b) $3.5 \mathrm{wt} \% \mathrm{NaCl}$ plus 500 ppmw ammonium bisulphite subject to internal pressure

Note: The picture on the left is (a) and the right is (b)

$997 \times 417 \mathrm{~mm}(96 \times 96$ DPI) 


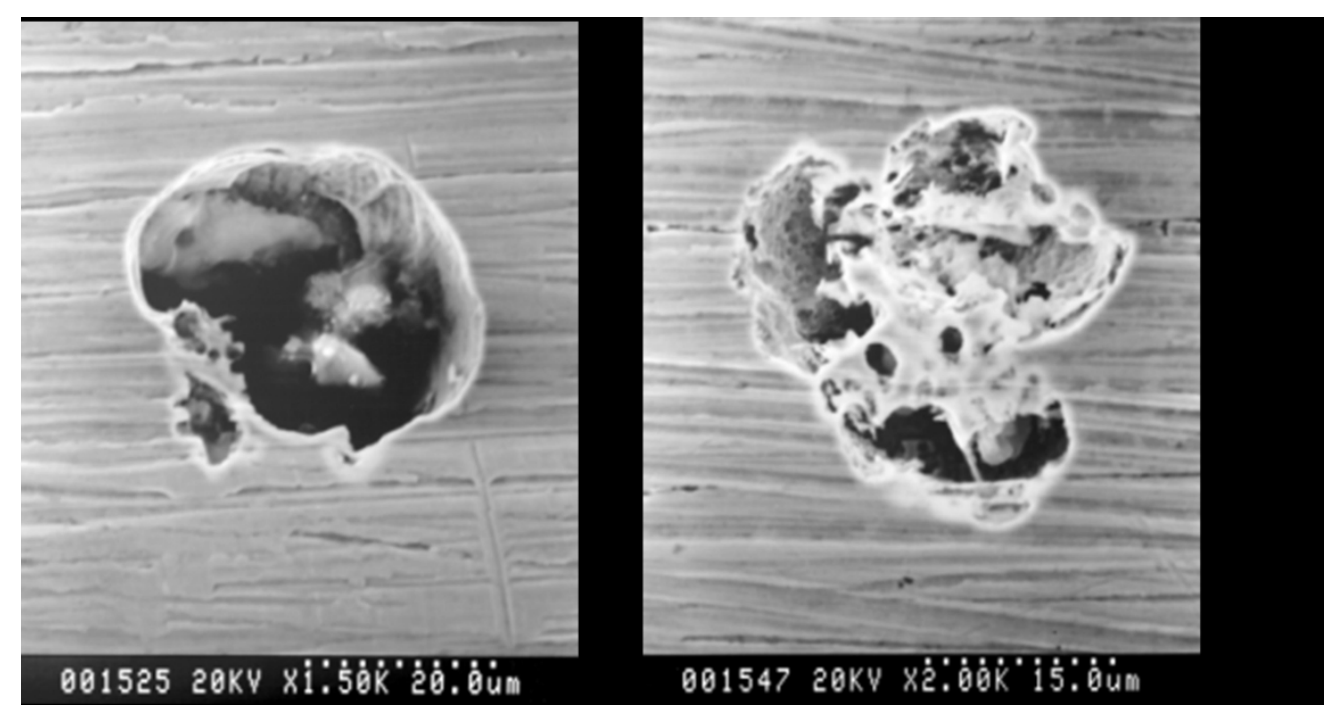

Effect of ammonium bisulphite concentration in $3.5 \mathrm{wt} \% \mathrm{NaCl}$ on the amount of deposits in pits on $25 \mathrm{Cr}$ SDSS pipes subjected to internal pressure and tested at 90 oC. (a) $3.5 \mathrm{wt} \% \mathrm{NaCl}$ plus $100 \mathrm{ppmw}$ ammonium bisulphite and (b) 3.5 wt\% NaCl plus 1000 ppmw ammonium bisulphite

Note: The picture on the left is (a) and the right is (b)

$997 \times 527 \mathrm{~mm}(96 \times 96 \mathrm{DPI})$ 


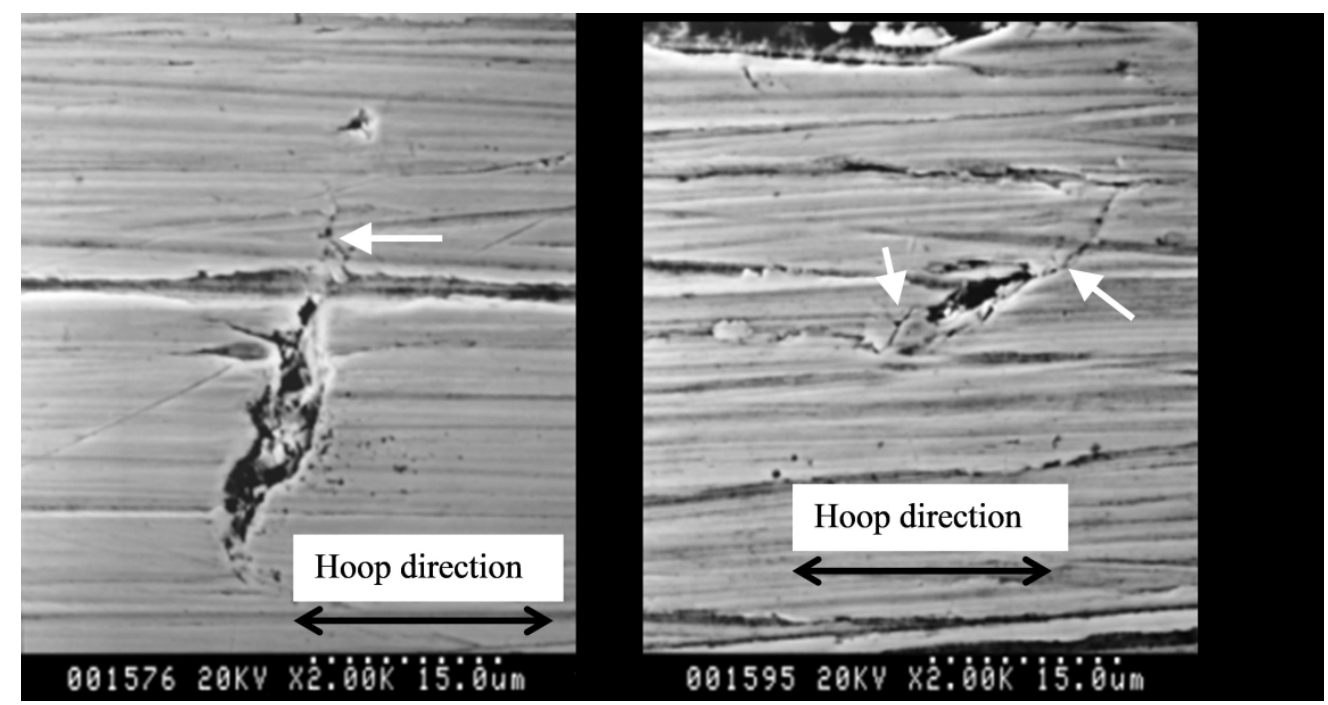

Typical crack initiation from pits on the surface of $25 \mathrm{Cr}$ SDSS mini pipe in $3.5 \mathrm{wt} \% \mathrm{NaCl}$ solutions plus different concentration of ammonium bisulphite. The white filled arrows indicate the cracks initiated from pits

Note: The picture on the left is (a) and the right is (b); (a) combined load ( 0 ppmw) and (b) combined load (500 ppmw)

$997 \times 527 \mathrm{~mm}(96 \times 96 \mathrm{DPI})$ 